\title{
F-18 Stilbenes As PET Imaging Agents For Detecting $\beta$-Amyloid Plaques In The Brain
}

\author{
Wei Zhang ${ }^{1}$, Shunichi Oya ${ }^{1}$, Mei-Ping Kung ${ }^{1}$, Catherine Hou ${ }^{1}$, Donna L. Maier ${ }^{2}$, and Hank F. \\ Kung ${ }^{1,3}$ \\ 1Department of Radiology, University of Pennsylvania, Philadelphia, PA 19104 \\ 2Department of Neuroscience, AstraZeneca, Wilmington, USA \\ 3Departments of Pharmacology, University of Pennsylvania, Philadelphia, PA 19104
}

\begin{abstract}
Imaging agents targeting $\beta$,-amyloid $(A \beta)$ may be useful for diagnosis and treatment of patients with Alzheimer's disease $(\mathrm{AD})$. Compounds $\mathbf{3 e}$ and $\mathbf{4 e}$ are fluorinated stilbene derivatives displaying high binding affinities for $\mathrm{A} \beta$ plaques in $\mathrm{AD}$ brain homogenates $\left(\mathrm{K}_{\mathrm{i}}=15 \pm 6\right.$ and $5.0 \pm 1.2 \mathrm{nM}$, respectively). In vivo biodistributions of $\left[{ }^{18} \mathrm{~F}\right] 3 \mathbf{e}$ and $\left[{ }^{18} \mathrm{~F}\right] \mathbf{4 e}$ in normal mice exhibited excellent brain penetrations ( 5.55 and $9.75 \%$ dose/g at $2 \mathrm{~min}$ ) and rapid brain washouts were observed, especially for $\left[{ }^{18} \mathrm{~F}\right] 4 \mathrm{e}(0.72 \% \mathrm{dose} / \mathrm{g}$ at $60 \mathrm{~min})$. They also showed in vivo plaque labeling in APP/PS1 or Tg2576 transgenic mice, animal models for AD. Autoradiography of postmortem AD brain sections and AD homogenate binding studies confirmed the selective and specific binding properties to $A \beta$ plaques. In conclusion, the preliminary results strongly suggest that these fluorinated stilbene derivatives, $\left[{ }^{18} \mathrm{~F}\right] \mathbf{3 e}$ and $\left[{ }^{18} \mathrm{~F}\right] \mathbf{4 e}$, are suitable candidates as $\mathrm{A} \beta$ plaque imaging agents for studying patients with $\mathrm{AD}$.
\end{abstract}

\section{Introduction}

Alzheimer's disease (AD) is a brain disorder associated with progressive memory loss and decrease of cognitive function. Currently, a definitive diagnosis of AD can only be established by demonstrating the presence of abundant senile plaques and neurofibrillary tangles in the postmortem brain 1,2 . The senile plaques are extra-cellular deposits of amyloid fibrils of $\beta$ amyloid $(A \beta)$, and their presence are strongly associated with pathogenesis of the disease. Thus, specific in vivo imaging agents targeting $A \beta$ plaques may serve as suitable markers for monitoring the amyloid burden following the disease progression and further provide supporting evidence for therapeutic intervention ${ }^{3}$. Currently, many efforts focusing on development of therapeutic approach targeting $A \beta$ plaques or reversing the effects of the plaque-deposition have been reported 4,5 .

Development of imaging agents for direct mapping of $A \beta$ aggregates in the living brain is an active research area in recent years. Several research groups have reported biomarkers for imaging $A \beta$ plaques in the brain $6-10$. The $A \beta$-plaque-specific imaging agents can be labeled with short-lived isotopes suitable for in vivo imaging studies ${ }^{10}$. Two isotopes, ${ }^{99 \mathrm{~m}} \mathrm{Tc}\left(\mathrm{T}_{1 / 2}, 6\right.$ $\mathrm{h}, 140 \mathrm{KeV})$ and ${ }^{123} \mathrm{I}\left(\mathrm{T}_{1 / 2}, 13 \mathrm{~h}, 159 \mathrm{KeV}\right)$, are commonly used for single photon emission

CORRESPONDING AUTHOR ADDRESS: Hank F. Kung, Ph.D. Department of Radiology University of Pennsylvania, 3700 Market Street'Room 305 Philadelphia, PA 19104.Tel: (215)662-3096, Fax: (215)349-5035; e-mail: kunghf@ sunmac.spect.upenn.edu.

Supporting Information Available: Elemental analysis data are available for the preparation of all compounds. This material is available free of charge via the Internet at http://pubs.acs.org. 
computed tomography (SPECT); while ${ }^{11} \mathrm{C}\left(\mathrm{T}_{1 / 2}, 20 \mathrm{~min}, 511 \mathrm{KeV}\right)$ and ${ }^{18} \mathrm{~F}\left(\mathrm{~T}_{1 / 2}, 110 \mathrm{~min}\right.$, $511 \mathrm{KeV}$ ) are often used for positron emission tomography (PET). It is generally accepted that SPECT is more convenient and cost-effective, but PET gives a better imaging resolution. Recently, successful preliminary reports using a ${ }^{11} \mathrm{C}$ labeled benzothiazole derivative, $\left[{ }^{11} \mathrm{C}\right]$ $\mathrm{PIB}^{6,11,12}$, and a ${ }^{18} \mathrm{~F}$ labeled probe, $\left[{ }^{18} \mathrm{~F}\right] \mathrm{FDDNP}{ }^{9,13,14}$, for plaque and tangle visualization in living $\mathrm{AD}$ patients have demonstrated the potential utility of in vivo imaging (Fig. 1). Similarly, our group has also prepared a ${ }^{11} \mathrm{C}$ labeled PET ligand, $\left[{ }^{11} \mathrm{C}\right] \mathrm{SB}-13(4-N-$ methylamino-4'-hydroxystilbene), a stilbene derivative 7,15 and a ${ }^{123}$ I labeled SPECT ligand, IMPY (6-iodo-2-(4'- $N, N$-dimethylamino)phenylimidazo[1,2-a]pyridine) ${ }^{16-18}$. Both tracersshowed selective and high binding affinities to $\mathrm{A} \beta$ plaques ${ }^{19}$. As expected, $\left[{ }^{11} \mathrm{C}\right] \mathrm{SB}-13$ displayed a high accumulation in the frontal cortex (presumably an area containing a high density of $\mathrm{A} \beta$ plaques) in mild to moderate $\mathrm{AD}$ patients, but not in age-matched control subjects ${ }^{7}$; while the SPECT ligand, [ ${ }^{123}$ I[IMPY, is currently under active clinical evaluation. Other structurally similar compounds have been recently reported for targeting $\mathrm{A} \beta$ plaques in the brain ${ }^{20-22}$.

Initially, we reported an iodinated derivative of stilbene, 3-iodo-4'-diamino-stilbene, targeting amyloid plaques for SPECT imaging ${ }^{23}$. However, the unfavorable in vivo kinetic properties make it unattractive for further development as a useful in vivo SPECT tracer for amyloid plaques in the brain. We have subsequently identified another stilbene derivative, SB-13, labeled with $\mathrm{C}-11$ as a potential PET tracer for plaque imaging ${ }^{15}$. It was clinically demonstrated that $\left[{ }^{11} \mathrm{C}\right] \mathrm{SB}-13$ can detect senile plaques present in $\mathrm{AD}$ patients 7 . However, the short half life (20 min) of C-11 may limit the usefulness of $\left[{ }^{11} \mathrm{C}\right] \mathrm{SB}-13$ or $\left[{ }^{11} \mathrm{C}\right] \mathrm{PIB}$ for a wide spread clinical application. One major focus of our effort is in development of ${ }^{18} \mathrm{~F}$ labeled plaque-specific imaging agents, because the longer half-life of F-18 and stability in solution allow the use of the radioligand over a long period of time. While this work was in progress a series of ${ }^{18} \mathrm{~F}$ labeled styrylbenzoxazole compounds, such as 2-(4-methylaminostyryl)-6-(2$\left[{ }^{18} \mathrm{~F}\right]$ fluoroethoxy) benzoxazole, were reported to show promise as potential PET imaging agents targeting amyloid plaques in the brain 8 .

Reported herein are the synthesis and in vitro and in vivo evaluations of a novel series of two ${ }^{18} \mathrm{~F}$ labeled stilbene derivatives as prospective $\mathrm{PET}$ radiotracers for imaging amyloid plaques in the brain.

\section{Results and Discussion}

\section{Chemistry}

Syntheses of compounds $\mathbf{3 e}, \mathbf{4 e}$ and radiolabelings of precursors $3 \mathbf{d}, \mathbf{5 h}$ to prepare $\left[{ }^{18} \mathrm{~F}\right] \mathbf{3 e}$ and $\left[{ }^{18} \mathrm{~F}\right] \mathbf{4 e}$ are shown in Scheme 1 and Scheme 4. To prepare compound 3a the nitro group of 4nitro-4'-hydroxy stilbene, 1a, was reduced with $\mathrm{SnCl}_{2} / \mathrm{HCl}(\mathrm{c})$ in ethanol to give the corresponding amine 2a. Following a treatment with $(\mathrm{CHO})_{\mathrm{n}}$ and $\mathrm{NaBH}_{3} \mathrm{CN}$, the dimethylamino compound 3a was obtained. Compound $\mathbf{3 b}$ was obtained by reacting the hydroxyl stilbene, $\mathbf{3 a}$, with bromide $\mathbf{8} \mathbf{m}^{24}$, which was separately prepared as shown in Scheme 2 , and potassium carbonate in anhydrous DMF. Compound $\mathbf{3 c}$ was obtained by treatment of $3 \mathbf{b}$ with $1 \mathrm{~N} \mathrm{HCl}$ in acetone to remove the protected group. Reacting diol $\mathbf{3 c}$ with 1.5 equivalent of tosyl chloride in pyridine gave a mixture; however, mono tosylate $\mathbf{3 d}$ could be isolated from the mixture by silica gel chromatography with $5 \%$ methanol in dichloromethane as the eluent. The tosylate group of $\mathbf{3 d}$ was converted to fluoride, $\mathbf{3 e}$, by refluxing with anhydrous TBAF in $\mathrm{THF}^{25}$. The tosyl compound $\mathbf{3 d}$ was also used as the starting material to obtain radiolabeled compound, $\left[{ }^{18} \mathrm{~F}\right] \mathbf{3 e}$. Nitro compound $1 \mathbf{e}$ was similarly synthesized by a coupling reaction of 1a with $\mathbf{8} \mathbf{m}^{24}$ followed by tosylation and fluorination. The synthesis of compound $4 \mathbf{e}$ was accomplished by reduction of the nitro group of $1 \mathbf{e}$ with $\mathrm{SnCl}_{2} / \mathrm{EtOH}$ followed by a monomethylation of the amino group with $(\mathrm{CHO})_{\mathrm{n}}, \mathrm{NaOCH}_{3}$ and $\mathrm{NaBH}_{4}$. The nitro group of 
the acetal protectecd intermediate, $\mathbf{1 b}$, was reduced to amine, $\mathbf{2} \mathbf{c}$, and then monomethylated to give compound $\mathbf{4 c}$. Similarly, 2a was first monomethylated to give the compound $\mathbf{4 a}$, after which $\mathbf{4 a}$ was coupled with $\mathbf{8 n}$ to give $\mathbf{5 f}$. Di-tert-butyl siliyl group of $\mathbf{5 f}$ was removed with $1 \mathrm{~N} \mathrm{TBAF}$ in THF at room temperature to give diol $\mathbf{5 c}$. The obtained $\mathbf{5 c}$ could be either monotosylated to give $\mathbf{5 d}$ or mono protected by THP 26 to give $\mathbf{5 g}$. From $\mathbf{5 g}$, the desired mesylated precusor $\mathbf{5 h}$ for radiolabeling can thus be obtained.

A related p-bromobenzyl compound $\mathbf{3 j}$ was also synthesized as shown in Scheme 3. The substituted malonate $9^{27}$ was reduced to diol 10 with DIBALH and then reacted with one equivalent of TBSCl to give 11. The unprotected $\mathrm{OH}$ was then converted into bromide $\mathbf{1 2}$ with $\mathrm{CBr}_{4} / \mathrm{PPh}_{3}$. Compound $\mathbf{1 2}$ was reacted with $\mathbf{3 a}$ to give $\mathbf{3 i}$ which was treated with TBAF to remove TBS group to yield $\mathbf{3 j}$.

Several starting materials were evaluated in a radiofluoride displacement reaction. To obtain dimethylamino derivative, $\left[{ }^{18} \mathrm{~F}\right] \mathbf{3 e}$, the tosylated precursor, $3 \mathbf{d d}$, was mixed with $\left[{ }^{18} \mathrm{~F}\right]$ fluoride/ potassium carbonate and Kryptofix ${ }^{\circledR} 222$ in DMSO and heated at $120^{\circ} \mathrm{C}$ for $4 \mathrm{~min}$. Crude product was purified by HPLC to attain $>99 \%$ of the radiochemical purity with $10 \%$ radiochemical yield (decay corrected). The procedure took $90 \mathrm{~min}$ and specific activity was estimated to be $70 \mathrm{Ci} / \mathrm{mmol}$ at the end of synthesis. To obtain the $N$-monomethyl derivative, $\left[{ }^{18} \mathrm{~F}\right] \mathbf{4 e}$, tosylate $\mathbf{5 d}$ was first prepared as the precursor for radiolabeling. However, the purification of $\left[{ }^{18} \mathrm{~F}\right] \mathbf{4 e}$ was tedious and time consuming resulting in a low yield. The situation was greatly improved when using $\mathbf{5} \mathbf{h}$ as the precursor for labeling, of which mesylate was used instead of tosylate and the free $\mathrm{OH}$ was protected with THP. An advantage of using mesylate $(\mathbf{5 h})$ as the radiolabeling precursor is that reaction proceeded more cleanly. As a result, the amount and the number of unknown side-products were significantly reduced. Specific activity estimated by comparing UV peak intensity of labeled compound with reference nonradioactive compound of known concentration improved at least 10 times at the end of synthesis comparing with that obtained from tosylated precursor, 5d. A similar procedure was carried out to obtain $\left[{ }^{18} \mathrm{~F}\right] \mathbf{4} \mathbf{e}$ from the mesylated precursor, $\mathbf{5} \mathbf{h}$. After the initial reaction in DMSO, the mixture was treated with aqueous $\mathrm{HCl}$ to remove BOC and THP groups. Radiochemical purity was $>99 \%$ after HPLC purification and the radiochemical yield was $20 \%$ (decay corrected). The total syntheses took $110 \mathrm{~min}$ and specific activity was estimated to be $900-1,000 \mathrm{Ci} / \mathrm{mmol}$ at the end of synthesis.

\section{Biological studies}

Binding affinities of the new series of stilbene derivatives were examined in a binding assay using AD brain homogenates and [ $\left.{ }^{125} \mathrm{I}\right] \mathrm{IMPY}$ as the radioligand ${ }^{19}$. Compound $\mathbf{4 a}(\mathrm{SB}-13)$, as shown previously, displayed a high binding affinity ${ }^{19}$. With an additional methyl group attached to the nitrogen atom (dimethylamino vs monomethylamino in 3a vs 4a), a similar high binding affinity was observed (1.1 $\mathrm{nM}$ and $1.2 \mathrm{nM}$ for $\mathbf{3 a}$ and $\mathbf{4 a}$, respectively)(Table 1). Further modifications of $\mathbf{3 a}$ result in epoxi and diol derivatives, $\mathbf{3} \mathbf{b}$ and $\mathbf{3} \mathbf{c}$, but they showed lower binding affinities $\left(\mathrm{K}_{\mathrm{i}}=59\right.$ and $38 \mathrm{nM}$, respectively). A relatively high binding affinity $\left(\mathrm{K}_{\mathrm{i}}=15 \mathrm{nM}\right)$ was obtained with $\mathbf{3 e}$ (a fluorinated derivative).

Since the binding affinity of $\mathbf{3 e}$ appeared promising; thus, the corresponding tosylated derivative, $\mathbf{3 d}$, was prepared as a starting material for radiolabeling with ${ }^{18} \mathrm{~F}$. Under the chosen HPLC conditions (Hamilton PRP-1 column, $\mathrm{CH}_{3} \mathrm{CN} /$ dimethylglutarate buffer $(5 \mathrm{mM}, \mathrm{pH}$ ) $=9 / 1$ ), the tosylated and the diol derivatives can be clearly separated from the desired ${ }^{18} \mathrm{~F}$ labeled stilbene, $\left[{ }^{18} \mathrm{~F}\right] 3 \mathrm{e}$. This HPLC system has been successfully applied to remove the potential pseudo-carrier, the hydroxyl compound, 3c. Similarly, the monomethylamino compounds displayed the same trend with a high affinity for the fluorinated derivative, $4 \mathbf{e}$ $\left(\mathrm{K}_{\mathrm{i}}=5 \mathrm{nM}\right)$, and a lower affinity for the diol derivative, $4 \mathbf{c}\left(\mathrm{K}_{\mathrm{i}}=32.5 \mathrm{nM}\right)$. In addition, extra p-bromo-benzyl substituted derivative such as $\mathbf{3 j}$, showed a lower binding affinity $\left(\mathrm{K}_{\mathrm{i}}=80\right.$ 
$\mathrm{nM})$. Interestingly, the free amino derivative, $\mathbf{2 e}$, under a similar binding assay condition, showed a $\mathrm{K}_{\mathrm{i}}$ value of $15 \pm 4.0 \mathrm{nM}$ which was comparable to the dimethylamino (3e) and monomethylamino (4e) derivatives (competing with [ ${ }^{125}$ I]IMPY binding) (Table 1). This result is different from the original stilbene compounds showing a much lower binding affinity for the free amino compound $\left(\mathrm{K}_{\mathrm{i}}=1.1,1.2\right.$ and $95 \mathrm{nM}$ for $\mathbf{3 a}, \mathbf{4 a}(\mathrm{SB}-13)$ and $\mathbf{2 a}$, respectively). Surprisingly, despite the fact that $2 \mathbf{e}$ showed reasonably good in vitro binding affinity (a relatively low $\mathrm{K}_{\mathrm{i}}$ value), $\left.{ }^{18} \mathrm{~F}\right] 2 \mathrm{e}$ exhibited no specific binding signal for amyloid plaques (using either $\mathrm{AD}$ brain section labeling or $\mathrm{AD}$ homogenate binding) (data not shown). Therefore, we have abandoned this free amino compound and focused only on $\left[{ }^{18} \mathrm{~F}\right] \mathbf{3 e}$ and $\left[{ }^{18} \mathrm{~F}\right] \mathbf{4 e}$ as likely candidates. As expected, both $\left[{ }^{18} \mathrm{~F}\right] 3 \mathbf{e}$ and $\left[{ }^{18} \mathrm{~F}\right] 4 \mathbf{e}$ clearly label plaques by in vitro autoradiography using postmortem $\mathrm{AD}$ brain sections showing a high plaque labeling and a low background (see Fig 2). The same results were obtained using brain sections of double transgenic (APP/PS1) mice (data not shown).

Previously, using an in vitro binding assay we have reported saturable and high binding affinities in postmortem brain homogenates of AD patients for two potential tracers, $\left[{ }^{3} \mathrm{H}\right] \mathrm{SB}-13$ (a $N$-methylamino derivative) and [ $\left.{ }^{125} \mathrm{I}\right] \mathrm{IMPY}$ (a $N, N$ - dimethylamino derivative) ${ }^{19}$.

Interestingly, $\left[{ }^{18} \mathrm{~F}\right] 3 \mathrm{e}$ contains a $N, N$-dimethylamino group, but it did not display any specific $\mathrm{A} \beta$ plaque binding signals in the brain homogenates binding assay (data not shown). However, using a mono- $N$-methylated derivative, $\left[{ }^{18} \mathrm{~F}\right] \mathbf{4} \mathbf{e}$, in the same binding assay, a distinct binding signal was observed in the gray matter homogenates of AD patients. In the white matter of $\mathrm{AD}$ patients, where $\mathrm{A} \beta$ plaque deposits were low to non-existent, the binding signal was significantly lower (6-8 times lower) (Fig. 4). Whereas in assays using brain homogenates from control subjects, the binding signals in both gray and white matters were low, suggesting that the binding was highly selective to the presence of $A \beta$ plaque deposits. The specific binding observed for $\left[{ }^{18} \mathrm{~F}\right] \mathbf{4 e}$ in $\mathrm{AD}$ brain homogenates was saturable and the binding capacity $\left(\mathrm{B}_{\max }\right)$ was in the range of $10-20 \mathrm{pmole} / \mathrm{mg}$ tissue (data not shown). Detailed in vitro binding characterization of $\left[{ }^{18} \mathrm{~F}\right] \mathbf{4 e}$ will be published elsewhere as a separate paper.

After an $i v$ injection, both $\left[{ }^{18} \mathrm{~F}\right] \mathbf{3 e}$ and $\left[{ }^{18} \mathrm{~F}\right] \mathbf{4 e}$ displayed good initial brain uptakes in normal mice $\left(5.55 \%\right.$ and $9.75 \% \mathrm{ID} / \mathrm{g}$ at 2 min post-injection for $\left[{ }^{18} \mathrm{~F}\right] 3 \mathbf{e}$ and $\left[{ }^{18} \mathrm{~F}\right] \mathbf{4 e}$, respectively). The rate of washout of $\left[{ }^{18} \mathrm{~F}\right] \mathbf{3 e}$ from the brain was slower as compared to that of $\left[{ }^{18} \mathrm{~F}\right] \mathbf{4 e}(1.37$ $\%$ and $0.31 \% \mathrm{ID} / \mathrm{g}$ at $120 \mathrm{~min}$ post-injection for $\left[{ }^{18} \mathrm{~F}\right] \mathbf{3 e}$ and $\left[{ }^{18} \mathrm{~F}\right] \mathbf{4 e}$, respectively). A relatively higher lipophilicity was observed for $\left[{ }^{18} \mathrm{~F}\right] \mathbf{3 e}$ (partition coefficient $=1,375$ and 889 for $\left[{ }^{18} \mathrm{~F}\right]$ $3 \mathbf{e}$ and $\left[{ }^{18} \mathrm{~F}\right] \mathbf{4 e}$, respectively). This disparity may account for the longer brain retention observed for $\left[{ }^{18} \mathrm{~F}\right] 3 \mathrm{e}$. Initial blood levels were relatively low for both tracers $(1.79 \%$ and $2.60 \%$ $\mathrm{ID} / \mathrm{g}$ for $\left[{ }^{18} \mathrm{~F}\right] \mathbf{3 e}$ and $\left[{ }^{18} \mathrm{~F}\right] \mathbf{4 e}$, respectively) and there was a significant reduction at $2 \mathrm{hr}$ postinjection $(1.18$ and $0.78 \% \mathrm{ID} / \mathrm{g})$. In vivo defluorination was likely for both tracers, because the bone uptake showed increasing uptake reaching $7-8 \% \mathrm{ID} / \mathrm{g}$ at $2 \mathrm{hr}$ post-injection.

To examine the in vivo labeling of $\mathrm{A} \beta$ plaques in a living brain, we have tested both candidates using mouse models, APP/PS1 ${ }^{8,28}$ or Tg2576 transgenic mice ${ }^{29}$, which are specifically engineered to over produce the $A \beta$ plaques in the brain. When subjected to in vivo labeling of $\mathrm{A} \beta$ plaques (after an $i v$ injection) in these models, distinctive $\mathrm{A} \beta$ plaque labeling can be observed for both $\left[{ }^{18} \mathrm{~F}\right] 3 \mathbf{e}$ and $\left[{ }^{18} \mathrm{~F}\right] \mathbf{4 e}$ (Fig. $3 \mathrm{~A}$ and $\mathrm{B}$ ). The specific in vivo targeting for $\mathrm{A} \beta$ plaques, especially for $\left[{ }^{18} \mathrm{~F}\right] \mathbf{4 e}$, demonstrates the feasibility of using it as an in vivo PET imaging agent for detecting senile plaques. Both of these transgenic mouse models have been successfully used in studying relationships between deposit of $A \beta$ plaques and $\mathrm{AD}^{30,31}$. For the purpose of this in vivo $\mathrm{A} \beta$ plaque labeling study by a ${ }^{18} \mathrm{Ftracer}$ in a transgenic mouse model we did not make a distinction between using either one of these models. Recently, the presence of soluble oligomer of amyloid- $\beta$ peptides, prior to their aggregation to fribrillary forms, has attracted attention as the primary underlying feature leading to neuronal toxicity and symptoms of $\mathrm{AD}^{32-34}$. The PET imaging agents reported in this paper will not be able to detect the soluble 
form of amyloid- $\beta$ peptides; however, the presence of the oligomers is likely a prelude leading to the formation of $\mathrm{A} \beta$ aggregates in the brain. Therefore, from a diagnostic perspective, imaging agents targeting $A \beta$ palques in the brain will still be very useful for the diagnosis of $A D$. Efforts in developing novel ligands for binding the soluble $A \beta$ oligomers will be an interesting and highly important research topic.

\section{Conclusion}

A new series of novel stilbene derivatives displaying high binding affinities to $A \beta$ plaques was successfully prepared as potential PET imaging agents for AD. Both 4-dimethylamino and 4monomethylamino stilbenes $\left(\left[{ }^{18} \mathrm{~F}\right] 3 \mathbf{e}\right.$ and $\left.\left[{ }^{18} \mathrm{~F}\right] 4 \mathbf{e}\right)$ entered the brain of normal mice readily and quickly. $\left[{ }^{18} \mathrm{~F}\right] \mathbf{4 e}$ showed a fast washout with a low normal brain retention. Specific plaque labeling was demonstrated by in vitro and ex vivo autoradiography of brain sections. Favorable pharmacokinetic properties and specific plaque labeling properties of these ${ }^{18} \mathrm{~F}$ labeled stilbene derivatives, especially $\left[{ }^{18} \mathrm{~F}\right] \mathbf{4 e}$, warrant further investigation.

\section{Experimental Section}

All reagents used in syntheses were commercial products and were used without further purification unless otherwise indicated. ${ }^{1} \mathrm{H}$ NMR spectra were obtained on a Bruker DPX spectrometer $(200 \mathrm{MHz})$ in $\mathrm{CDCl}_{3}$ unless otherwise indicated. Chemical shifts are reported as $\delta$ values (parts per million) relative to internal TMS. Coupling constants are reported in Hertz. The multiplicity is defined by s (singlet), $\mathrm{d}$ (doublet), $\mathrm{t}$ (triplet), br (broad), $\mathrm{m}$ (multiplet). Elemental analyses were performed by Atlantic Microlab INC. For each procedure, "standard workup" refers to the following steps: addition of indicated organic solvent, washing the organic layer with water then brine, separation of the organic layer from the aqueous layer, drying off the combined organic layers with anhydrous sodium sulfate, filtering off the sodium sulfate and removing the organic solvent under reduced pressure.

\section{4-Amino-4'-hydroxystilbene (2a)}

Stannous chloride (11.8 g, $0.062 \mathrm{~mol}$ ) was added to a solution of compound 1a (Frinton Lab) $(3.0 \mathrm{~g}, 0.012 \mathrm{~mol})$ in ethanol $(100 \mathrm{~mL})$ followed by the addition of concentrated hydrochloric acid $(5.0 \mathrm{~mL})$. The solution was brought to reflux for $3 \mathrm{hr}$ and cooled to room temperature stirring overnight. Aqueous sodium hydroxide (1N) was added to adjust the $\mathrm{pH}$ to 8-9. After standard workup with dichloromethane, crude product $\mathbf{2 a}$ was obtained and was used in the following step without further purifications. 2a $(2.6 \mathrm{~g}, \sim 100 \%):{ }^{1} \mathrm{H}$ NMR (DMSO-d $\left.{ }_{6}\right) \delta 9.39$ $(\mathrm{s}, 1 \mathrm{H}), 7.30(\mathrm{~d}, 2 \mathrm{H}, J=8.5 \mathrm{~Hz}), 7.20(\mathrm{~d}, 2 \mathrm{H}, J=8.5 \mathrm{~Hz}), 6.80(\mathrm{~m}, 2 \mathrm{H}), 6.72(\mathrm{~d}, 2 \mathrm{H}, J=8.5$ $\mathrm{Hz}), 6.53(\mathrm{~d}, 2 \mathrm{H}, \mathrm{J}=8.5 \mathrm{~Hz}), 5.19(\mathrm{~s}, 2 \mathrm{H})$.

\section{4-N,N'-Dimethylamino-4'-hydroxystilbene (3a)}

To a mixture of $2 \mathbf{a}(211 \mathrm{mg}, 1.0 \mathrm{mmol})$, paraformaldehyde $(300 \mathrm{mg}, 10 \mathrm{mmol})$ and sodium cyanoborohydride $(189 \mathrm{mg}, 3.0 \mathrm{mmol})$, acetic acid $(10 \mathrm{~mL})$ was added. The whole mixture was stirred at room temperature overnight and then poured into $100 \mathrm{~mL}$ of water. Sodium carbonate was added to adjust the $\mathrm{pH}$ to 8-9. After standard workup with $5 \%$ methanol in dichloromethane, the residue was purified by silica gel column chromatography $(2.5 \%$ methanol in dichloromethane) to afford $\mathbf{3 a}$ as a white solid (214 mg, $89.5 \%):{ }^{1} \mathrm{H}$ NMR $\delta 7.37$ (m, 4H), $6.87(\mathrm{~s}, 2 \mathrm{H}), 6.75(\mathrm{~m}, 4 \mathrm{H}), 4.68(\mathrm{~s}, 1 \mathrm{H}), 2.98(\mathrm{~s}, 6 \mathrm{H})$.

\section{(4-\{2-[4-(2,2-Dimethyl-[1,3]dioxan-5-ylmethoxy)-phenyl]-vinyl\}-phenyl)-dimethyl-amine (3b)}

Under a nitrogen atmosphere, 3a (100 mg, $0.38 \mathrm{mmol})$ was dissolved in anhydrous DMF (5.0 $\mathrm{mL})$. Potassium carbonate $(140 \mathrm{mg}, 1.0 \mathrm{mmol})$ was added to this solution followed by 5 bromomethyl-2,2-dimethyl-[1,3]dioxane $8 \mathbf{m}^{24}$ (105 $\left.\mathrm{mg}, 0.5 \mathrm{mmol}\right)$. The mixture was heated 
to $100{ }^{\circ} \mathrm{C}$ and stirred overnight. After cooling down to room temperature, standard workup with dichloromethane was applied and the residue was purified by silica gel preparative TLC (1\% methanol in dichloromethane) to afford compound $\mathbf{3 b}(100 \mathrm{mg}, 72 \%):{ }^{1} \mathrm{H}$ NMR $\delta 7.38$ $(\mathrm{m}, 4 \mathrm{H}), 6.88(\mathrm{~m}, 4 \mathrm{H}), 6.70(\mathrm{~d}, 2 \mathrm{H}, J=8.7 \mathrm{~Hz}), 4.08(\mathrm{~m}, 4 \mathrm{H}), 3.87(\mathrm{~m}, 2 \mathrm{H}), 2.96(\mathrm{~s}, 6 \mathrm{H}), 2.13$ $(\mathrm{m}, 1 \mathrm{H}), 1.46(\mathrm{~s}, 3 \mathrm{H}), 1.42(\mathrm{~s}, 3 \mathrm{H})$. Anal. $\left(\mathrm{C}_{23} \mathrm{H}_{29} \mathrm{NO}_{3}\right) \mathrm{C}, \mathrm{H}, \mathrm{N}$.

2-\{4-[2-(4-Dimethylamino-phenyl)-vinyl]-phenoxymethyl\}-propane-1,3-diol (3c)

Compound $3 \mathbf{b}(180 \mathrm{mg}, 0.49 \mathrm{mmol})$ was suspended in acetone $(5.0 \mathrm{~mL})$ and cooled to $0{ }^{\circ} \mathrm{C}$ with an ice bath. $1 \mathrm{~N} \mathrm{HCl}(5.0 \mathrm{~mL}, 5.0 \mathrm{mmol})$ was slowly added over $20 \mathrm{~min}$. The suspension turned into a clear solution during the addition. The solution was stirred at $0{ }^{\circ} \mathrm{C}$ for an additional $1.5 \mathrm{hr}$ and then warmed to room temperature in $0.5 \mathrm{hr}$. Saturated sodium bicarbonate was added to adjust $\mathrm{pH}$ to 8-9. After standard workup with dichloromethane, the residue was purified by silica gel preparative TLC (5\% methanol in dichloromethane) to afford compound $\mathbf{3 c}$ as a white solid (140 mg, $87 \%):{ }^{1} \mathrm{H}$ NMR $\delta 7.40(\mathrm{~m}, 4 \mathrm{H}), 6.88(\mathrm{~m}, 4 \mathrm{H}), 6.74(\mathrm{~m}, 2 \mathrm{H}), 4.10(\mathrm{~d}, 2 \mathrm{H}$, $J=5.47 \mathrm{~Hz}), 3.89(\mathrm{~d}, 4 \mathrm{H}, J=5.28 \mathrm{~Hz}), 2.98(\mathrm{~s}, 6 \mathrm{H}), 2.22(\mathrm{~m}, 1 \mathrm{H})$. Anal. $\left(\mathrm{C}_{20} \mathrm{H}_{25} \mathrm{NO}_{3}\right)$ C. H. $\mathrm{N}$.

\section{Toluene-4-sulfonic acid-3-\{4-[2-(4-dimethylamino-phenyl)-vinyl]-phenoxy\}-2- hydroxymethyl-propyl ester (3d)}

Compound 3c (158 mg, $0.49 \mathrm{mmol})$ was dissolved in anhydrous pyridine $(15 \mathrm{~mL})$ and cooled to $0{ }^{\circ} \mathrm{C}$ with an ice bath. Tosyl chloride $(137 \mathrm{mg}, 0.72 \mathrm{mmol}$ ) was added and the solution was stirred at $0{ }^{\circ} \mathrm{C}$ for $2 \mathrm{hr}$. After standard workup with dichloromethane, the residue was purified by silica gel preparative TLC ( $5 \%$ methanol in dichloromethane) to afford monotosylate compound, 3d, as a white solid (95 mg, $41 \%)$ : ${ }^{1} \mathrm{H}$ NMR $\delta 7.75(\mathrm{~d}, 2 \mathrm{H}, J=8.26 \mathrm{~Hz}), 7.37(\mathrm{~m}$, $4 \mathrm{H}), 7.26(\mathrm{~m}, 2 \mathrm{H}), 6.88(\mathrm{~m}, 2 \mathrm{H}), 6.72(\mathrm{~m}, 4 \mathrm{H}), 4.26(\mathrm{~d}, 2 \mathrm{H}, J=5.66 \mathrm{~Hz}), 3.97(\mathrm{~d}, 2 \mathrm{H}, J=5.96$ $\mathrm{Hz}), 3.79(\mathrm{~d}, 2 \mathrm{H}, J=5.24 \mathrm{~Hz}), 2.95(\mathrm{~s}, 6 \mathrm{H}), 2.38(\mathrm{~m}, 4 \mathrm{H})$. Anal. $\left(\mathrm{C}_{27} \mathrm{H}_{31} \mathrm{NO}_{5} \mathrm{~S}\right) \mathrm{C}, \mathrm{H}, \mathrm{N}$.

\section{3-\{4-[2-(4-Dimethylamino-phenyl)-vinyl]-phenoxy\}-2-fluoromethyl-propan-1-ol (3e)}

Compound 3d (40 mg, $0.083 \mathrm{mmol}$ ) was dissolved in anhydrous THF (5.0 mL). Under the nitrogen atmosphere, anhydrous TBAF 25 (150 mg, $0.5 \mathrm{mmol})$ in anhydrous THF $(1.0 \mathrm{~mL})$ was slowly added. The solution was then heated to reflux for $3 \mathrm{hr}$. After cooled down to room temperature, standard workup with dichloromethane was applied and the residue was applied for silica gel preparative TLC ( $5 \%$ methanol in dichloromethane) to afford product $3 \mathrm{e}(17 \mathrm{mg}$, $62 \%):{ }^{1} \mathrm{H}$ NMR $\delta 7.40(\mathrm{~m}, 4 \mathrm{H}), 6.89(\mathrm{~m}, 4 \mathrm{H}), 6.70(\mathrm{~d}, 2 \mathrm{H}, J=8.82 \mathrm{~Hz}), 4.67\left(\mathrm{~d} \mathrm{~d}, 2 \mathrm{H}, J^{1}=\right.$ $\left.47.1 \mathrm{~Hz}, J^{2}=5.46 \mathrm{~Hz}\right), 4.10(\mathrm{~d}, 2 \mathrm{H}, J=5.86 \mathrm{~Hz}), 3.88(\mathrm{~d}, 2 \mathrm{H}, J=5.24 \mathrm{~Hz}), 2.97(\mathrm{~s}, 6 \mathrm{H}), 2.40$ $(\mathrm{m}, 1 \mathrm{H}), 1.76(\mathrm{~s}, 1 \mathrm{H})$. Anal. $\left(\mathrm{C}^{20} \mathrm{H}^{24} \mathrm{FNO}^{2}\right) \mathrm{C}, \mathrm{H}, \mathrm{N}$.

\section{2,2-Dimethyl-5-\{4-[2-(4-nitro-phenyl)-vinyl]-phenoxymethyl\}-[1,3]dioxane(1b)}

Compound $\mathbf{1 b}$ was prepared from $1 \mathrm{a}(241 \mathrm{mg}, 1.0 \mathrm{mmol})$ with the same procedure described for compound 3b. 1b $(260 \mathrm{mg}, 70 \%):{ }^{1} \mathrm{H}$ NMR $\beta 8.19(\mathrm{~d}, 2 \mathrm{H}, J=8.80 \mathrm{~Hz}), 7.49(\mathrm{~m}, 4 \mathrm{H}), 7.07$ $(\mathrm{m}, 2 \mathrm{H}), 6.90(\mathrm{~d}, 2 \mathrm{H}, J=8.80 \mathrm{~Hz}), 4.12(\mathrm{~m}, 4 \mathrm{H}), 3.89(\mathrm{~d}, 2 \mathrm{H}), 2.10(\mathrm{~m}, 1 \mathrm{H}), 1.48(\mathrm{~s}, 3 \mathrm{H}), 1.43$ (s, 3H). Anal. calcd. $\left(\mathrm{C}_{21} \mathrm{H}_{23} \mathrm{NO}_{5}\right) \mathrm{C}, \mathrm{H}, \mathrm{N}$.

\section{2-\{4-[2-(4-Nitro-phenyl)-vinyl]-phenoxymethyl\}-propane-1,3-diol (1c)}

Compound $\mathbf{1 c}$ was prepared from $\mathbf{1 b}(260 \mathrm{mg}, 0.7 \mathrm{mmol})$ with the same procedure described for compound 3c. 1c $(190 \mathrm{mg}, 82 \%):{ }^{1} \mathrm{H} \mathrm{NMR}\left(\mathrm{CD}_{3} \mathrm{OD}\right) \delta 8.19(\mathrm{~d}, 2 \mathrm{H}, J=8.80 \mathrm{~Hz}), 7.72(\mathrm{~d}$, $2 \mathrm{H}, J=8.80 \mathrm{~Hz}), 7.55(\mathrm{~d}, 2 \mathrm{H}, J=8.70 \mathrm{~Hz}), 7.24(\mathrm{q}, 2 \mathrm{H}), 6.96(\mathrm{~d}, 2 \mathrm{H}, J=8.70 \mathrm{~Hz}), 4.09(\mathrm{~d}$, $2 \mathrm{H}, J=5.78 \mathrm{~Hz}), 3.74(\mathrm{~d}, 4 \mathrm{H}, J=5.94 \mathrm{~Hz}), 2.14(\mathrm{~m}, 1 \mathrm{H})$. Anal. $\left(\mathrm{C}_{18} \mathrm{H}_{19} \mathrm{NO}_{5}\right) \mathrm{C}, \mathrm{H}, \mathrm{N}$. 
Toluene-4-sulfonic acid 2-hydroxymethyl-3-\{4-[2-(4-nitro-phenyl)-vinyl]-phenoxy\}-propyl ester (1d)

Compound 1d was prepared from $1 \mathbf{c}(80 \mathrm{mg}, 0.24 \mathrm{mmol})$ with the same procedure described for compound 3d. 1d (66mg, $56 \%$ ): ${ }^{1} \mathrm{HNMR} \delta 8.18(\mathrm{~d}, 2 \mathrm{H}, J=8.82 \mathrm{~Hz}), 7.77(\mathrm{~d}, 2 \mathrm{H}, J=8.32$ $\mathrm{Hz}), 7.58(\mathrm{~d}, 2 \mathrm{H}, J=8.82 \mathrm{~Hz}), 7.45(\mathrm{~d}, 2 \mathrm{H}, J=8.73 \mathrm{~Hz}), 7.28(\mathrm{~d}, 2 \mathrm{H}, J=8.18 \mathrm{~Hz}), 7.09(\mathrm{q}$, $2 \mathrm{H}), 6.81(\mathrm{~d}, 2 \mathrm{H}, J=8.73 \mathrm{~Hz}), 4.27(\mathrm{~d}, 2 \mathrm{H}, J=5.70 \mathrm{~Hz}), 4.01(\mathrm{~m}, 2 \mathrm{H}), 3.80(\mathrm{~d}, 2 \mathrm{H}, J=5.61$ $\mathrm{Hz}), 2.40(\mathrm{~m}, 4 \mathrm{H}), 2.02(\mathrm{~s}, 1 \mathrm{H})$. Anal. $\left(\mathrm{C}_{25} \mathrm{H}_{25} \mathrm{NO}_{7} \mathrm{~S}\right) \mathrm{C}, \mathrm{H}, \mathrm{N}$.

\section{2-Fluoromethyl-3-\{4-[2-(4-nitro-phenyl)-vinyl]-phenoxy\}-propan-1-ol (1e).}

Compound 1e was prepared from $1 \mathbf{d}(33 \mathrm{mg}, 0.069 \mathrm{mmol})$ with the same procedure described for compound 3e. 1e $(20 \mathrm{mg}, 88 \%):{ }^{1} \mathrm{H}$ NMR $\delta 8.19(\mathrm{~d}, 2 \mathrm{H}, J=8.83 \mathrm{~Hz}), 7.58(\mathrm{~d}, 2 \mathrm{H}, J=8.84$ $\mathrm{Hz}), 7.48(\mathrm{~d}, 2 \mathrm{H}, J=8.74 \mathrm{~Hz}), 7.10(\mathrm{q}, 2 \mathrm{H}), 6.94(\mathrm{~d}, 2 \mathrm{H}, J=8.68 \mathrm{~Hz}), 4.69\left(\mathrm{~d} \mathrm{~d}, 2 \mathrm{H}, J_{1}=47.1\right.$ $\left.\mathrm{Hz}, J_{2}=5.36 \mathrm{~Hz}\right), 4.15(\mathrm{~d}, 2 \mathrm{H}, J=5.89 \mathrm{~Hz}), 3.90(\mathrm{~d}, 2 \mathrm{H}, J=5.43 \mathrm{~Hz}), 2.43(\mathrm{~m}, 1 \mathrm{H}), 1.74(\mathrm{~s}$, 1H). Anal. $\left(\mathrm{C}_{18} \mathrm{H}_{18} \mathrm{FNO}_{4}\right) \mathrm{C}, \mathrm{H}, \mathrm{N}$.

\section{3-\{4-[2-(4-Amino-phenyl)-vinyl]-phenoxy\}-2-fluoromethyl-propan-1-ol (2e)}

Compound $2 \mathrm{e}$ was prepared from $1 \mathrm{e}(37 \mathrm{mg}, 0.11 \mathrm{mmol})$ with the same procedure described for compound 2a. 2e (24 mg, $71 \%):{ }^{1} \mathrm{H}$ NMR $\beta 7.35$ (m, 4H), $6.90(\mathrm{~m}, 4 \mathrm{H}), 6.66(\mathrm{~d}, 2 \mathrm{H}, J=$ $8.54 \mathrm{~Hz}), 4.69\left(\mathrm{~d} \mathrm{~d}, 2 \mathrm{H}, J_{1}=47.1 \mathrm{~Hz}, J_{2}=5.46 \mathrm{~Hz}\right), 4.12(\mathrm{~d}, 2 \mathrm{H}, J=5.84 \mathrm{~Hz}), 3.90(\mathrm{~d}, 2 \mathrm{H}$, $J=5.56 \mathrm{~Hz}), 3.70(\mathrm{~s}, 2 \mathrm{H}), 2.39(\mathrm{~m}, 1 \mathrm{H}), 1.71(\mathrm{~s}, 1 \mathrm{H})$. Anal. $\left(\mathrm{C}_{18} \mathrm{H}_{20} \mathrm{FNO}_{2}\right) \mathrm{C}, \mathrm{H}, \mathrm{N}$.

\section{2-Fluoromethyl-3-\{4-[2-(4-methylamino-phenyl)-vinyl]-phenoxy\}-propan-1-ol (4e)}

Under the nitrogen atmosphere, sodium methoxide ( $22 \mathrm{mg}, 0.4 \mathrm{mmol})$ was added to a suspension of compound $2 \mathrm{e}(24 \mathrm{mg}, 0.08 \mathrm{mmol})$ in methanol $(6 \mathrm{~mL})$ followed by paraformaldehyde ( $12 \mathrm{mg}, 0.4 \mathrm{mmol})$. The solution was heated to reflux for $2 \mathrm{hr}$ and cooled to $0{ }^{\circ} \mathrm{C}$ with an ice bath. Sodium borohydride $(15 \mathrm{mg}, 0.4 \mathrm{mmol})$ was added in portions. Reaction mixture was brought to reflux again for $1 \mathrm{hr}$ and poured onto crushed ice. After standard workup with dichloromethane, the residue was applied for silica gel preparative TLC (4.5\% methanol in dichloromethane) to afford product $4 \mathrm{e}(23 \mathrm{mg}, 92 \%):{ }^{1} \mathrm{H}$ NMR $\delta 7.37(\mathrm{~m}, 4 \mathrm{H}), 6.87(\mathrm{~m}$, $4 \mathrm{H}), 6.59(\mathrm{~d}, 2 \mathrm{H}, J=8.56 \mathrm{~Hz}), 4.69\left(\mathrm{~d}, \mathrm{~d}, 2 \mathrm{H}, J_{1}=47.1 \mathrm{~Hz}, J_{2}=5.44 \mathrm{~Hz}\right), 4.12(\mathrm{~d}, 2 \mathrm{H}, J=$ $5.86 \mathrm{~Hz}), 4.00(\mathrm{~s}, 1 \mathrm{H}), 3.89$. (d, $2 \mathrm{H}, \mathrm{J}=5.52 \mathrm{~Hz}), 2.86(\mathrm{~s}, 3 \mathrm{H}), 2.41(\mathrm{~m}, 1 \mathrm{H}), 1.75(\mathrm{~s}, 1 \mathrm{H})$. Anal. $\left(\mathrm{C}_{19} \mathrm{H}_{22} \mathrm{FNO}_{2}\right) \mathrm{C}, \mathrm{H}, \mathrm{N}$.

\section{4-N-Methylamino-4'-hydroxystilbene (4a)}

Compound $4 \mathbf{a}$ was prepared from $\mathbf{2 a}(105 \mathrm{mg}, 0.5 \mathrm{mmol})$ with the same procedure as described for compound 4e.4a $(100 \mathrm{mg}, 89 \%):{ }^{1} \mathrm{H}$ NMR $\delta 7.34(\mathrm{~m}, 4 \mathrm{H}), 6.86(\mathrm{~s}, 2 \mathrm{H}), 6.79(\mathrm{~d}, 2 \mathrm{H}, J=$ $8.58 \mathrm{~Hz}), 6.60(\mathrm{~d}, 2 \mathrm{H}, J=8.58 \mathrm{~Hz}), 2.85(\mathrm{~s}, 3 \mathrm{H})$.

\section{(2,2-Di-tert-butyl-[1,3,2]dioxasilinan-5-yl)-methanol (7n)}

To the solution of 2-hydroxypropyl-1,3-diol $6(500 \mathrm{mg}, 4.7 \mathrm{mmol})$ in anhydrous dichloromethane $(15 \mathrm{~mL})$, HOBT $(135 \mathrm{mg}, 1.0 \mathrm{mmol})$ was added. Under the nitrogen atmosphere, triethylamine $(6.5 \mathrm{~mL}, 4.9 \mathrm{~g}, 48 \mathrm{mmol})$ was added via a syringe followed by ditert-butyl-dichlorosilane (1.05 g, $5.0 \mathrm{mmol})$. The solution was gently refluxed for $1 \mathrm{hr}$ and cooled to room temperature. After standard workup with dichloromethane, the residue was applied for silica gel column chromatography (1\% methanol in dichloromethane) to afford product 7n, which was used for the following step without further purification. 7n $(1.03 \mathrm{~g}, 89$ $\%):{ }^{1} \mathrm{H}$ NMR $\delta 4.17(\mathrm{~m}, 2 \mathrm{H}), 3.92(\mathrm{t}, 2 \mathrm{H}), 3.50(\mathrm{~d}, 2 \mathrm{H}, J=5.78 \mathrm{~Hz}), 2.30(\mathrm{~m}, 1 \mathrm{H}), 1.39(\mathrm{~s}$, 1H), $1.04(\mathrm{~s}, 9 \mathrm{H}), 1.02(\mathrm{~s}, 9 \mathrm{H})$. 


\section{5-Bromomethyl-2,2-di-tert-butyl-[1,3,2]dioxasilinan (8n)}

Compound $7 \mathbf{n}(123 \mathrm{mg}, 0.5 \mathrm{mmol})$ was dissolved in dichloromethane $(10 \mathrm{~mL})$ and cooled to $-10{ }^{\circ} \mathrm{C}$ with an ethanol-ice bath. Pyridine $(1 \mathrm{~mL})$ was added followed by carbon tetrabromide $(220 \mathrm{mg}, 0.66 \mathrm{mmol})$. Triphenylphosphine $(174 \mathrm{mg}, 0.66 \mathrm{mmol})$ was added in portions and the solution was stirred at $-10{ }^{\circ} \mathrm{C}$ for $2 \mathrm{hr}$ then raised to room temperature overnight. Solvent was removed under reduced pressure and residue was applied for silica gel column chromatography ( $10 \%$ ethyl acetate in hexane) to afford compound $\mathbf{8 n}$, which was used in the following step without further purification. 8n $(130 \mathrm{mg}, 84 \%):{ }^{1} \mathrm{H}$ NMR $\delta 4.20(\mathrm{~m}, 2 \mathrm{H}), 3.93$ $(\mathrm{t}, 2 \mathrm{H}), 3.20(\mathrm{~d}, 2 \mathrm{H}, J=6.19 \mathrm{~Hz}), 2.39(\mathrm{~m}, 1 \mathrm{H}), 1.04(\mathrm{~s}, 9 \mathrm{H}), 1.01(\mathrm{~s}, 9 \mathrm{H})$.

\section{(4-\{2-[4-(2,2-Di-tert-butyl-[1,3,2]dioxasilinan-5-ylmethoxy)-phenyl]-vinyl\}-phenyl)-methyl- amine (4f)}

Under the nitrogen atmosphere, compound $4 \mathbf{a}(90 \mathrm{mg}, 0.4 \mathrm{mmol})$ was dissolved in anhydrous DMF $(15.0 \mathrm{~mL})$. Potassium carbonate $(560 \mathrm{mg}, 4.0 \mathrm{mmol})$ was added followed by 5 bromomethyl-2,2-di-tert-butyl-[1,3,2]dioxasilinan, $8 \mathbf{n}$ (127 $\mathrm{mg}, 0.4 \mathrm{mmol})$. The suspension was heated to $100^{\circ} \mathrm{C}$ and stirred overnight. After cooling to room temperature, standard workup with dichloromethane was applied and the residue was purified by silica gel preparative TLC (dichloromethane) to afford compound $\mathbf{4 f}(115 \mathrm{mg}, 63 \%)$ : ${ }^{1} \mathrm{HNMR} \delta 7.38(\mathrm{~m}, 4 \mathrm{H}), 6.88(\mathrm{~s}$, $2 \mathrm{H}), 6.82(\mathrm{~d}, 2 \mathrm{H}, J=8.64 \mathrm{~Hz}), 6.73(\mathrm{~d}, 2 \mathrm{H}, J=8.42), 5.80(\mathrm{~s}, 1 \mathrm{H}), 4.26(\mathrm{~m}, 2 \mathrm{H}), 4.04(\mathrm{t}, 2 \mathrm{H})$, $3.81(\mathrm{~d}, 2 \mathrm{H}, J=5.82 \mathrm{~Hz}), 2.89(\mathrm{~s}, 3 \mathrm{H}), 2.58(\mathrm{~m}, 1 \mathrm{H}), 1.06(\mathrm{~s}, 9 \mathrm{H}), 1.04(\mathrm{~s}, 9 \mathrm{H})$. Anal. $\left(\mathrm{C}_{27} \mathrm{H}_{39} \mathrm{NO}_{3} \mathrm{Si}\right) \mathrm{C}, \mathrm{H}, \mathrm{N}$.

\section{(4-\{2-[4-(2,2-Di-tert-butyl-[1,3,2]dioxasilinan-5-ylmethoxy)-phenyl]-vinyl\}-phenyl)-methyl- carbamic acid tert-butyl ester (5f)}

BOC anhydride (320 mg, $1.46 \mathrm{mmol})$ was added to a solution of compound $\mathbf{4 f}(110 \mathrm{mg}, 0.24$ $\mathrm{mmol})$ in anhydrous THF $(10 \mathrm{~mL})$. Under the protection of nitrogen, triethylamine $(1.0 \mathrm{~mL})$ was added via a syringe. The solution was then refluxed for $34 \mathrm{hr}$. After cooling down to room temperature, standard workup with dichloromethane was applied. Organic solvent was removed under reduced pressure and the residue was purified through silica gel column chromatography to afford compound $\mathbf{5 f}$, which was used in the following step without further purification. 5f $(122 \mathrm{mg}, 91 \%):{ }^{1} \mathrm{HNMR} \delta 7.42(\mathrm{~d}, 4 \mathrm{H}, J=7.52 \mathrm{~Hz}), 7.20(\mathrm{~d}, 2 \mathrm{H}, J=8.52$ $\mathrm{Hz}), 6.98(\mathrm{~m}, 2 \mathrm{H}), 6.84(\mathrm{~d}, 2 \mathrm{H}, J=8.72 \mathrm{~Hz}), 4.26(\mathrm{~m}, 2 \mathrm{H}), 4.05(\mathrm{t}, 2 \mathrm{H}), 3.82(\mathrm{~d}, 2 \mathrm{H}, J=5.84$ $\mathrm{Hz}), 3.27(\mathrm{~s}, 3 \mathrm{H}), 2.58(\mathrm{~m}, 1 \mathrm{H}), 1.46(\mathrm{~s}, 9 \mathrm{H}), 1.06(\mathrm{~s}, 9 \mathrm{H}), 1.04(\mathrm{~s}, 9 \mathrm{H})$.

\section{(4-\{2-[4-(3-Hydroxy-2-hydroxymethyl-propoxy)-phenyl]-vinyl\}-phenyl)-methyl-carbamic acid tert-butyl ester (5c)}

Compound $\mathbf{5 f}(120 \mathrm{mg}, 0.22 \mathrm{mmol})$ was dissolved in anhydrous THF $(10 \mathrm{~mL})$ and the solution was cooled to $0{ }^{\circ} \mathrm{C}$ with an ice bath. Under the nitrogen atmosphere, TBAF $(0.44 \mathrm{~mL}, 1 \mathrm{M}$ in THF, $0.44 \mathrm{mmol}$ ) was added via a syringe. The solution was stirred at $0{ }^{\circ} \mathrm{C}$ for $0.5 \mathrm{hr}$ and then brought to room temperature for another $2 \mathrm{hr}$. After standard workup with dichloromethane, the residue was applied for silica gel preparative TLC (5\% methanol in dichloromethane) to afford compound $\mathbf{5 c}(89 \mathrm{mg}, 99 \%):{ }^{1} \mathrm{H}$ NMR $\delta 7.43(\mathrm{~d}, 4 \mathrm{H}, J=8.68 \mathrm{~Hz}), 7.20(\mathrm{~d}, 2 \mathrm{H}, J=8.56$ $\mathrm{Hz}), 6.98(\mathrm{~m}, 2 \mathrm{H}), 6.90(\mathrm{~d}, 2 \mathrm{H}, J=8.74 \mathrm{~Hz}), 4.14(\mathrm{~d}, 2 \mathrm{H}, J=5.96 \mathrm{~Hz}), 3.95(\mathrm{~d}, 4 \mathrm{H}, J=5.24$ $\mathrm{Hz}), 3.27(\mathrm{~s}, 3 \mathrm{H}), 2.27(\mathrm{~m}, 1 \mathrm{H}), 1.70(\mathrm{~s}, 2 \mathrm{H}), 1.46(\mathrm{~s}, 9 \mathrm{H})$. Anal. $\left(\mathrm{C}_{24} \mathrm{H}_{31} \mathrm{NO}_{5}\right) \mathrm{C}, \mathrm{H}, \mathrm{N}$.

\section{[4-(2-\{4-[2-Hydroxymethyl-3-(tetrahydro-pyran-2-yloxy)-propoxy]-phenyl\}-vinyl)-phenyl]- methyl-carbamic acid tert-butyl ester $(5 \mathrm{~g})$}

A solution of $5 \mathbf{c}(53 \mathrm{mg}, 0.13 \mathrm{mmol})$ and 3, 4-dihydropyran $(12.9 \mathrm{mg}, 0.15 \mathrm{mmol})$ in drydichloromethane $(12 \mathrm{ml})$ containing pyridinium $p$-toluene sulfonate ${ }^{26} .(3.3 \mathrm{mg}, 0.013 \mathrm{~mol})$ was stirred at room temperature for $4 \mathrm{hr}$. After standard workup with dichloromethane, the residue was applied for silica gel preparative TLC (5\% methanol in dichloromethane) to afford 
compound $\mathbf{5 g}$, which was used in the following step without further purifications. $5 \mathbf{g}$ (43 $\mathrm{mg}$, $67 \%$ ): ${ }^{1} \mathrm{H}$ NMR $\delta 7.43(\mathrm{~d}, 4 \mathrm{H}, J=8.46 \mathrm{~Hz}), 7.20(\mathrm{~d}, 2 \mathrm{H}, J=8.46 \mathrm{~Hz}), 6.97(\mathrm{~m}, 2 \mathrm{H}), 6.90(\mathrm{~d}$, $2 \mathrm{H}, J=8.62 \mathrm{~Hz}), 4.60(\mathrm{~b}, 1 \mathrm{H}), 3.95(\mathrm{~m}, 6 \mathrm{H}), 3.70(\mathrm{~m}, 1 \mathrm{H}), 3.54(\mathrm{~m}, 1 \mathrm{H}), 3.26(\mathrm{~s}, 3 \mathrm{H}), 2.34(\mathrm{~m}$, $1 \mathrm{H}), 1.70(\mathrm{~m}, 6 \mathrm{H}), 1.46(\mathrm{~s}, 9 \mathrm{~h})$.

\section{Methanesulfonic acid 3-(4-\{2-[4-(tert-butoxycarbonyl-methyl-amino)-phenyl]-vinyl\}- phenoxy)-2-(tetrahydro-pyran-2-yloxymethyl)-propyl ester(5h)}

Triethylamine $(0.2 \mathrm{ml})$ was added to a solution of compound $5 \mathrm{~g}(43 \mathrm{mg}, 0.087 \mathrm{mmol})$ and methanesulfonyl chloride $(29.7 \mathrm{mg}, 0.26 \mathrm{mmol})$ in drydichloromethane $(10 \mathrm{ml})$. The solution was stirred at room temperature for $3.5 \mathrm{hr}$. After standard work up with dichloromethane, the residue was applied for silicagel preparative TLC ( $2 \%$ methanol in dichloromethane) to afford compound $\mathbf{5 h}(43 \mathrm{mg}, 86 \%):{ }^{1} \mathrm{H}$ NMR $\delta 7.43(\mathrm{~d}, 4 \mathrm{H}, J=8.58 \mathrm{~Hz}), 7.20(\mathrm{~d}, 2 \mathrm{H}, J=8.46 \mathrm{~Hz})$, $6.97(\mathrm{~m}, 2 \mathrm{H}), 6.90(\mathrm{~d}, 2 \mathrm{H}, J=8.62 \mathrm{~Hz}), 4.59(\mathrm{~b}, 1 \mathrm{H}), 4.46(\mathrm{~d}, 2 \mathrm{H}, J=5.66 \mathrm{~Hz}), 4.11(\mathrm{~m}, 2 \mathrm{H})$, $3.85(\mathrm{~m}, 2 \mathrm{H}), 3.55(\mathrm{~m}, 2 \mathrm{H}), 3.27(\mathrm{~s}, 3 \mathrm{H}), 3.00(\mathrm{~s}, 3 \mathrm{H}), 2.59(\mathrm{~m}, 1 \mathrm{H}), 1.70(\mathrm{~m}, 6 \mathrm{H}), 1.46(\mathrm{~s}, 9 \mathrm{~h})$. HRMS m/Z calcd. For $\mathrm{C}_{30} \mathrm{H}_{41} \mathrm{NO}_{8} \mathrm{~S}\left(\mathrm{M}^{+} \mathrm{Na}^{+}\right)$: 598.2451. Found: 598.2444.

\section{2-\{4-[2-(4-Amino-phenyl)-vinyl]-phenoxymethyl\}-propane-1,3-diol (2c)}

Compound $\mathbf{2 c}$ was prepared from $\mathbf{1 b}(200 \mathrm{mg}, 0.54 \mathrm{mmol})$ with the same procedure described for 2a and was used in the following step without further purifications. 2c (144 mg, 89 $\%$ ): ${ }^{1} \mathrm{H}$ NMR (DMSO- $\left.d^{6}\right) \delta 7.40(\mathrm{~d}, 2 \mathrm{H}, J=8.58 \mathrm{~Hz}), 7.22(\mathrm{~d}, 2 \mathrm{H}, J=8.30 \mathrm{~Hz}), 6.91(\mathrm{~m}, 4 \mathrm{H})$, $6.54(\mathrm{~d}, 2 \mathrm{H}, J=8.30 \mathrm{~Hz}), 5.22(\mathrm{~s}, 2 \mathrm{H}), 4.51(\mathrm{t}, 2 \mathrm{H}, \mathrm{J}=5.11 \mathrm{~Hz}), 3.97(\mathrm{~d}, 2 \mathrm{H}, J=5.85 \mathrm{~Hz})$, $3.51(\mathrm{t}, 4 \mathrm{H}), 1.96(\mathrm{~m}, 1 \mathrm{H})$.

\section{2-\{4-[2-(4-Methylamino-phenyl)-vinyl]-phenoxymethyl\}-propane-1,3-diol(4c)}

Compound $\mathbf{4 c}$ was prepared from $2 \mathbf{c}(100 \mathrm{mg}, 0.33 \mathrm{mmol})$ with the same procedure described for 4a. 4c (104 mg, 99\%): ${ }^{1} \mathrm{H}$ NMR (DMSO- $\left.d_{6}\right) \delta 7.42(\mathrm{~d}, 2 \mathrm{H}, J=8.58 \mathrm{~Hz}), 7.30(\mathrm{~d}, 2 \mathrm{H}, J=$ $8.46 \mathrm{~Hz}), 6.88(\mathrm{~m}, 4 \mathrm{H}), 6.52(\mathrm{~d}, 2 \mathrm{H}, J=8.42 \mathrm{~Hz}), 5.80(\mathrm{~m}, 1 \mathrm{H}), 4.51(\mathrm{t}, 2 \mathrm{H}), 3.97(\mathrm{~d}, 2 \mathrm{H}, J=$ $5.85 \mathrm{~Hz}), 3.51(\mathrm{t}, 4 \mathrm{H}, J=5.95 \mathrm{~Hz}), 2.68(\mathrm{~d}, 3 \mathrm{H}, J=4.7 \mathrm{~Hz}), 1.95(\mathrm{~m}, 1 \mathrm{H})$. Anal. $\left(\mathrm{C}_{19} \mathrm{H}_{23} \mathrm{NO}_{3}\right) \mathrm{C}, \mathrm{H}, \mathrm{N}$.

\section{2-(4-Bromo-benzyl)-propane-1,3-diol (10)}

2-(4-Bromo-benzyl)-malonic acid diethyl ester $9^{27}$ (1.5 g, $\left.3.8 \mathrm{mmol}\right)$ was dissolved in $5 \mathrm{~mL}$ THF and the solution was added slowly to DIBALH (1M in toluene, $25 \mathrm{~mL}$ ) via a syringe at $0{ }^{\circ} \mathrm{C}$ and stirred at the same temperature for $3 \mathrm{hr} . \mathrm{HCl}(2 \mathrm{~N}, 50 \mathrm{~mL})$ was then added to break the complex. After standard work up with ethyl acetate, crude product $\mathbf{1 0}(0.9 \mathrm{~g}, 99 \%)$ was obtained, which was used directly for the next step without further purification: ${ }^{1} \mathrm{H}$ NMR $\delta$ 7.39 (d, 2H, $J=8.2 \mathrm{~Hz}), 7.04$ (d, 2H, $J=8.2 \mathrm{~Hz}), 3.60$ (m, 4H), 2.55 (d, 2H, $J=7.4 \mathrm{~Hz}), 1.96$ (m, 1H).

\section{3-(4-Bromo-phenyl)-2-(tert-butyl-dimethyl-silanyloxymethyl)-propan-1-ol>(11)}

Under the nitrogen atmosphere, tert-butyl-chloro-dimethyl silane (246 $\mathrm{mg}, 1.63 \mathrm{mmol})$ was added to a solution of compound $\mathbf{1 0}(400 \mathrm{mg}, 1.63 \mathrm{mmol})$ in dichloromethane $(10 \mathrm{~mL})$ at 0 。 $\mathrm{C}$, followed by triethylamine $(412 \mathrm{mg}, 4.07 \mathrm{mmol})$. The solution was gradually warmed to room temperature and stirred overnight. After standard work up with dichloromethane, the residue was purified by silica gel preparative TLC ( $40 \%$ ethyl acetate in hexane) to afford compound $11(370 \mathrm{mg}, 63.2 \%):{ }^{1} \mathrm{H}$ NMR $\delta 7.41(\mathrm{~d}, 2 \mathrm{H}, J=6.6 \mathrm{~Hz}), 7.08(\mathrm{~d}, 2 \mathrm{H}, J=6.6 \mathrm{~Hz})$, $3.66(\mathrm{~m}, 4 \mathrm{H}), 2.60(\mathrm{~m}, 2 \mathrm{H}), 1.94(\mathrm{~m}, 1 \mathrm{H}), 0.91(\mathrm{~s}, 9 \mathrm{H}), 0.06(\mathrm{~s}, 6 \mathrm{H})$. 


\section{[2-Bromomethyl-3-(4-bromo-phenyl)-propoxy]-tert-butyl-dimethyl-silane(12)}

Compound $\mathbf{1 2}$ was prepared from $\mathbf{1 1}(80 \mathrm{mg}, 0.22 \mathrm{mmol})$ with the same procedure described for $\mathbf{8 m}{ }^{24}$ and was used in the following step without further purifications. 12 (70 $\mathrm{mg}, 75$ $\%):{ }^{1} \mathrm{H}$ NMR $\delta 7.40(\mathrm{~d}, 2 \mathrm{H}, J=6.6 \mathrm{~Hz}), 7.07(\mathrm{~d}, 2 \mathrm{H}, J=6.6 \mathrm{~Hz}), 3.46(\mathrm{~m}, 4 \mathrm{H}), 2.73(\mathrm{~d}, 2 \mathrm{H}$, $J=7.2 \mathrm{~Hz}), 2.03(\mathrm{~m}, 1 \mathrm{H}), 0.94(\mathrm{~s}, 9 \mathrm{H}), 0.06(\mathrm{~s}, 6 \mathrm{H})$.

\section{[4-(2-\{4-[2-(4-Bromo-benzyl)-3-(tert-butyl-dimethyl-silanyloxy)-propoxy]-phenyl\}-vinyl)- phenyl]-dimethyl-amine (3i)}

Compound $3 \mathbf{i}$ was prepared from $12(50 \mathrm{mg}, 0.12 \mathrm{mmol})$ and $\mathbf{3 a}(28 \mathrm{mg}, 0.12 \mathrm{mmol})$ with the same procedure for $\mathbf{3 b}$. This product was used in the following step without further purifications. 3i (40 mg, $59 \%) .{ }^{1} \mathrm{H}$ NMR $\delta 7.40(\mathrm{~m}, 6 \mathrm{H}), 7.09(\mathrm{~d}, 2 \mathrm{H}, J=8.2 \mathrm{~Hz}), 6.84(\mathrm{~m}$, $4 \mathrm{H}), 6.72(\mathrm{~d}, 2 \mathrm{H}, J=8.8 \mathrm{~Hz}), 3.91(\mathrm{~d}, 2 \mathrm{H}, J=5.4 \mathrm{~Hz}), 3.67(\mathrm{~m}, 2 \mathrm{H}), 2.99(\mathrm{~s}, 6 \mathrm{H}), 2.75(\mathrm{~d}, 2 \mathrm{H}$, $J=7.4 \mathrm{~Hz}), 2.20(\mathrm{~m}, 1 \mathrm{H}), 0.91(\mathrm{~s}, 9 \mathrm{H}), 0.04(\mathrm{~s}, 6 \mathrm{H})$.

\section{2-(4-Bromo-benzyl)-3-\{4-[2-(4-dimethylamino-phenyl)-vinyl]-phenoxy\}-propan-1-ol (3j)}

Compound $\mathbf{3 j}$ was prepared from $\mathbf{3 i}(40 \mathrm{mg}, 0.069 \mathrm{mmol})$ with the same procedure described for $5 \mathbf{c} .3 \mathbf{j}(19 \mathrm{mg}, 59 \%):{ }^{1} \mathrm{H}$ NMR $\delta: 7.40(\mathrm{~m}, 4 \mathrm{H}), 7.07(\mathrm{~d}, 2 \mathrm{H}, J=8.2 \mathrm{~Hz}), 6.87(\mathrm{~m}, 4 \mathrm{H})$, $6.70(\mathrm{~d}, 2 \mathrm{H}, J=8.2 \mathrm{~Hz}), 3.94(\mathrm{~m}, 2 \mathrm{H}), 3.75$ (b, 2H), 2.97 (s, 6H), 2.76 (d, $2 \mathrm{H}, J=7.4 \mathrm{~Hz}), 2.23$ $(\mathrm{m}, 1 \mathrm{H}), 1.78(\mathrm{~s}, 1 \mathrm{H})$. Anal. $\left(\mathrm{C}_{26} \mathrm{H}_{28} \mathrm{BrNO}_{2}\right) \mathrm{C}, \mathrm{H}, \mathrm{N}$.

\section{$\left[{ }^{18} \mathrm{~F}\right] 3-\{4-[2-(4-D i m e t h y l a m i n o-p h e n y l)-v i n y l]-p h e n o x y\}-2-f l u o r o m e t h y l-p r o p a n-1-o l ~\left(\left[{ }^{18} \mathrm{~F}\right] 3 e\right)$}

$\left[{ }^{18} \mathrm{~F}\right]$ Fluoride, produced by a cyclotron using ${ }^{18} \mathrm{O}(\mathrm{p}, \mathrm{n}){ }^{18} \mathrm{~F}$ reaction, was passed through a SepPak Light QMA cartridge as an aqueous solution in $\left[{ }^{18} \mathrm{O}\right]$-enriched water. The cartridge was dried by airflow, and the ${ }^{18} \mathrm{~F}$ activity was eluted with $2 \mathrm{~mL}$ of Kryptofix $222(\mathrm{~K} 222) / \mathrm{K}_{2} \mathrm{CO}_{3}$ solution (22 mg of $\mathrm{K} 222$ and $4.6 \mathrm{mg}$ of $\mathrm{K}_{2} \mathrm{CO}_{3}$ in $\mathrm{CH}_{3} \mathrm{CN} / \mathrm{H}_{2} \mathrm{O}$ 1.77/0.23). The solvent was removed at $120^{\circ} \mathrm{C}$ under an argon stream. The residue was azeotropically dried with $1 \mathrm{~mL}$ of anhydrous $\mathrm{CH}_{3} \mathrm{CN}$ twice at $120^{\circ} \mathrm{C}$ under an argon stream. A solution of tosylate precursor 3d $(4 \mathrm{mg})$ in DMSO $(0.2 \mathrm{~mL})$ was added to the reaction vessel containing the dried ${ }^{18} \mathrm{~F}$ activities. The solution was heated at $120^{\circ} \mathrm{C}$ for $4 \mathrm{~min}$. Water $(2 \mathrm{~mL})$ was added, and the mixture was extracted with ethyl acetate $(1 \mathrm{~mL} \times 2)$. The combined organic layer was dried $\left(\mathrm{Na}_{2} \mathrm{SO}_{4}\right)$, and the solvent was removed using an argon stream with gentle heating $\left(55-60^{\circ} \mathrm{C}\right)$. The residue was dissolved in $\mathrm{CH}_{3} \mathrm{CN}$ and injected to HPLC for purification [Hamilton PRP-1 column ( $7.0 \times 305 \mathrm{~mm}, 10 \mu \mathrm{m}) ; \mathrm{CH}_{3} \mathrm{CN} /$ dimethylglutarate buffer $(5 \mathrm{mM}, \mathrm{pH} 7)=9 / 1$; flow rate $=2 \mathrm{~mL} / \mathrm{min})$. Retention time of $\mathbf{3 e}$ was $11 \mathrm{~min}$ and well separated from precursor $\mathbf{3 d}(\mathrm{rt}=13$ min). Same HPLC condition was used for quality control (RCP >99\%). Specific activity was estimated by comparing UV peak intensity of purified $\left[{ }^{\mathbf{1 8}} \mathbf{F}\right] \mathbf{3 e}$ reference non-radioactive compound of known concentration. Specific activity was estimated to be $70 \mathrm{Ci} / \mathrm{mmol}$ after the preparation.

\section{$\left[{ }^{18} \mathrm{~F}\right] 2-F l u o r o m e t h y l-3-\{4-[2-(4-m e t h y l a m i n o-p h e n y l)-v i n y l]-p h e n o x y\}-p r o p a n-1-o l ~\left(\left[{ }^{18} \mathrm{~F}\right] 4 \mathrm{e}\right)$}

The labeling reaction was carried out as described above for dimethyl amino compound. The mesylate $\mathbf{5 h}(4 \mathrm{mg})$ was used as the precursor for the labeling. After the initial reaction at $120^{\circ}$ $\mathrm{C}$ in DMSO, $1 \mathrm{~mL}$ of $\mathrm{H}_{2} \mathrm{O}$ was added and the solution was cooled down for $1 \mathrm{~min} .1 \mathrm{~mL}$ of $10 \% \mathrm{HCl}$ was then added and the mixture was heated at $120^{\circ} \mathrm{C}$ again for $10 \mathrm{~min}$. Aqueous solution of $\mathrm{NaOH}$ was added to adjust the $\mathrm{pH}$ to basic. The mixture was extracted with ethyl acetate $(1 \mathrm{~mL} \times 2)$ and the combined organic layer was dried $\left(\mathrm{Na}_{2} \mathrm{SO}_{4}\right)$, and the solvent removed under argon stream with gentle heating $\left(55-60^{\circ} \mathrm{C}\right)$. The residue was dissolved in $\mathrm{CH}_{3} \mathrm{CN}$ and injected to HPLC for purification [Hamilton PRP-1 column (7.0 x $305 \mathrm{~mm}, 10$ $\mu \mathrm{m}) ; \mathrm{CH}_{3} \mathrm{CN} /$ dimethylglutarate buffer $(5 \mathrm{mM}, \mathrm{pH} 7)=9 / 1$; flow rate $\left.=2 \mathrm{~mL} / \mathrm{min}\right)$. Retention time of $4 \mathrm{e}$ was $10 \mathrm{~min}$ and well separated from precursor $\mathbf{5 h}(\mathrm{rt}=13 \mathrm{~min})$ as well as the hydrolysis by-product of precursor $(\mathrm{rt}=8 \mathrm{~min})$. Same HPLC condition was used for quality 
control (RCP $>99 \%$ ). Specific activity was estimated by comparing UV peak intensity of purified $\left[{ }^{18} \mathbf{F}\right] \mathbf{4 e}$ with reference non-radioactive compound of known concentration. Specific activity was estimated to be $900-1000 \mathrm{Ci} / \mathrm{mmol}$ after the preparation.

Preparation of brain tissue homogenates-Postmortem brain tissues were obtained from control and AD patients at autopsy, and neuropathological diagnosis was confirmed by current criteria (NIA-Reagan Institute Consensus Group, 1997). Homogenates were then prepared from dissected gray and white matters from pooled control and AD patients in phosphate buffered saline (PBS, pH 7.4) at the concentration of approximately $100 \mathrm{mg}$ wet tissue/ml (motor-driven glass homogenizer with setting of 6 for 30sec). The homogenates were aliquoted into $1 \mathrm{ml}$-portions and stored at $-70^{\circ} \mathrm{C}$ for 3-6 month without loss of binding signal.

Binding studies-[ ${ }^{125}$ I]IMPY with $2200 \mathrm{Ci} / \mathrm{mmole}$ specific activity and greater than $95 \%$ radiochemical purity was prepared using the standard iododestannylation reaction, and purified by a simplified C-4 mini column as described previously 18 . Binding assays were carried out in $12 \times 75 \mathrm{~mm}$ borosilicate glass tubes. The reaction mixture contained $50 \mu \mathrm{l}$ of brain homogenates $(20-50 \mu \mathrm{g}), 50 \mu \mathrm{l}$ of $\left[{ }^{125} \mathrm{I}\right] \mathrm{IMPY}(0.04-0.06 \mathrm{nM}$ diluted in PBS) and $50 \mu \mathrm{l}$ of inhibitors $\left(10^{-5}-10^{-10} \mathrm{M}\right.$ diluted serially in PBS containing $0.1 \%$ bovine serum albumin, BSA) in a final volume of $1 \mathrm{ml}$. Nonspecific binding was defined in the presence of IMPY (600 nM) in the same assay tubes. A similar assay condition for $\left[{ }^{18} \mathrm{~F}\right] \mathbf{4 e}$ was used for binding in a range of concentration between 0.3-0.5 nM. The non-specific binding was defined in the presence of nonradioactive $4 \mathbf{e}(1,000 \mathrm{nM})$. The mixture was incubated at $37^{\circ} \mathrm{C}$ for $2 \mathrm{hr}$ and the bound and the free radioactivity were separated by vacuum filtration through Whatman GF/B filters using a Brandel M-24R cell harvester followed by $2 \times 3 \mathrm{ml}$ washes of PBS at room temperature. Filters containing the bound ${ }^{125} \mathrm{I}$ or ${ }^{18} \mathrm{~F}$ ligand were assayed for radioactivity content in a gamma counter (Packard 5000) with 70\% counting efficiency. Under the assay conditions, the specifically bound fraction was less than $15 \%$ of the total radioactivity. The results of inhibition experiments were subjected to nonlinear regression analysis using EBDA by which $\mathrm{K}_{\mathrm{i}}$ values were calculated.

Film autoradiography-Brain sections from $\mathrm{AD}$ subjects were obtained by freezing the brain in powdered dry ice and cut into 20 micrometer-thick sections. The sections were incubated with $\left[{ }^{18} \mathrm{~F}\right]$ tracers $(200,000-250,000 \mathrm{cpm} / 200 \mu 1)$ for $1 \mathrm{hr}$ at room temperature. The sections were then dipped in saturated $\mathrm{Li}_{2} \mathrm{CO}_{3}$ in $40 \% \mathrm{EtOH}$ (two two-minute washes) and washed with $40 \% \mathrm{EtOH}$ (one two-minute wash) followed by rinsing with water for $30 \mathrm{sec}$. After drying, the ${ }^{18}$ F-labeled sections were exposed to Kodak MR film overnight.

In vivo plaque labeling with $\left[{ }^{18} \mathrm{~F}\right] 3 \mathrm{e}$ and $\left[{ }^{18} \mathrm{~F}\right] 4 \mathrm{e}-$ The in vivo evaluation was performed using either double transgenic APP/PS1 or single transgenic APP2576 mice which were kindly provided by AstraZeneca. After anesthetizing with $1 \%$ isoflurane, $250-300 \mu \mathrm{Ci}$ of $\left[{ }^{18} \mathrm{~F}\right] \mathbf{3 e}$ or $\left[{ }^{18} \mathrm{~F}\right] 4 \mathrm{e}$ in $200 \mu \mathrm{l}$ of $0.1 \%$ BSA solution was injected through the tail vein. The animals were allowed to recover for 60-120 min and then killed by decapitation. The brains were immediately removed and frozen in powdered dry ice. Sections of 20 micrometers were cut and exposed to Kodak MR film for overnight.Exvivofilm autoradiograms were thus obtained.

Organ distribution in normal mice-While under isoflurane anesthesia, $0.15 \mathrm{~mL}$ of a $0.1 \%$ bovine serum albumin solution containing $\left[{ }^{18} \mathrm{~F}\right]$ tracers $(5-10 \mu \mathrm{Ci})$ were injected directly into the tail vein of ICR mice (22-25 g, male) The mice ( $\mathrm{n}=3$ for each time point) were sacrificed by cervical dislocation at $120 \mathrm{~min}$ post injection. The organs of interest were removed and weighed, and the radioactivity was assayed for radioactivity content with an automatic gamma counter. The percentage dose per organ was calculated by a comparison of the tissue counts to suitably diluted aliquots of the injected material. Total activities of blood were 
calculated under the assumption that they were $7 \%$ of the total body weight. The $\%$ dose/g of samples was calculated by comparing the sample counts with the count of the diluted initial dose.

Partition coefficient-Partition coefficients were measured by mixing the $\left[{ }^{18} \mathrm{~F}\right]$ tracer with $3 \mathrm{~g}$ each of 1-octanol and buffer (0.1 M phosphate, $\mathrm{pH} 7.4)$ in a test tube. The test tube was vortexed for $3 \mathrm{~min}$ at room temperature, followed by centrifugation for $5 \mathrm{~min}$. Two weighed samples $(0.5 \mathrm{~g}$ each) from the 1-octanol and buffer layers were counted in a well counter. The partition coefficient was determined by calculating the ratio of $\mathrm{cpm} / \mathrm{g}$ of 1-octanol to that of buffer. Samples from the 1-octanol layer were re-partitioned until consistent partitions of coefficient values were obtained (usually the $3^{\text {rd }}$ or $4^{\text {th }}$ partition). The measurement was done in triplicate and repeated three times.

\section{Supplementary Material}

Refer to Web version on PubMed Central for supplementary material.

\section{Acknowledgements}

This work was supported by the grant from the National Institute of Health (AG022559 to H.F.K). APP/PS1 and $\mathrm{Tg} 2576$ transgenic mice were kindly provided by AstraZeneca. PIB was kindly provided by Dr. A Verbruggen in Katholieke Universiteit, Leuven.

\section{References}

(1). Hardy J, Selkoe DJ. The amyloid hypothesis of Alzheimer' disease: progress and problems on the road to therapeutics. Science 2002;297:353-356. [PubMed: 12130773]

(2). Ginsberg, SD.; Schmidt, ML.; Crino, PB.; Eberwine, JH.; Lee, VM-Y.; Trojanowski, JQ. Cerebralcortex: neurodegenerative and age-related changes in structure and function of cerebral cortex. Kluwer Academic/Plenum; New York: 1999. Molecular pathology of Alzheimer's disease and related disorders; p. 603-654.

(3). Selkoe DJ. Imaging Alzheimer' amyloid. Nature Biotech 2000;18:823-824.

(4). Wolfe MS. Therapeutic strategies for Alzheimer' disease. Nat Rev Drug Discov 2002;1:859-866. [PubMed: 12415246]

(5). Bachurin SO. Medicinal chemistry approaches for the treatment and prevention of Alzheimer' disease. Med Res Rev 2003;23:48-88. [PubMed: 12424753]

(6). Klunk WE, Engler H, Nordberg A, Wang Y, Blomqvist G, Holt DP, Bergstrom M, Savitcheva I, Huang G.-f. Estrada S, Ausen B, Debnath ML, Barletta J, Price JC, Sandell J, Lopresti BJ, Wall A, Koivisto P, Antoni G, Mathis CA, Langstrom B. Imaging Brain Amyloid in Alzheimer' Disease with Pittsburgh Compound-B. Ann. Neurol 2004;55:306-319. [PubMed: 14991808]

(7). Verhoeff NP, Wilson AA, Takeshita S, Trop L, Hussey D, Singh K, Kung HF, Kung M-P, Houle S. In vivo imaging of Alzheimer disease beta-amyloid with [11C]SB-13 PET. Am. J. Geriatr. Psychiatry 2004;12:584-595. [PubMed: 15545326]

(8). Okamura N, Suemoto T, Shimadzu H, Suzuki M, Shiomitsu T, Akatsu H, Yamamoto T, Staufenbiel M, Yanai K, Arai H, Sasaki H, Kudo Y, Sawada T. Styrylbenzoxazole derivatives for in vivo imaging of amyloid plaques in the brain. J. Neurosci 2004;24:2535-2541. [PubMed: 15014129]

(9). Shoghi-Jadid K, Small GW, Agdeppa ED, Kepe V, Ercoli LM, Siddarth P, Read S, Satyamurthy N, Petric A, Huang SC, Barrio JR, Liu J, Flores-Torres S, Cole GM. Localization of neurofibrillary tangles and beta-amyloid plaques in the brains of living patients with Alzheimer disease: Binding characteristics of radiofluorinated 6-dialkylamino-2-naphthylethylidene derivatives as positron emission tomography imaging probes for beta-amyloid plaques in Alzheimer disease. Am. J. Geriatr. Psychiatry 2002;10:24-35. [PubMed: 11790632]

(10). Mathis CA, Wang Y, Klunk WE. Imaging b-amyloid plaques and neurofibrillary tangles in the aging human brain. Curr. Pharm. Des 2004;10:1469-1492. [PubMed: 15134570] 
(11). Mathis CA, Wang Y, Holt DP, Huang G.-f. Debnath ML, Klunk WE. Synthesis and Evaluation of ${ }^{11}$ C-Labeled 6-Substituted 2- Arylbenzothiazoles as Amyloid Imaging Agents. J. Med. Chem 2003;46:2740-2754. [PubMed: 12801237]

(12). Wang Y, Klunk WE, Debnath ML, Huang GF, Holt DP, Shao L, Mathis CA. Development of a PET/SPECT agent for amyloid imaging in Alzheimer' disease. J Mol Neurosci 2004;24:55-62. [PubMed: 15314250]

(13). Agdeppa ED, Kepe V, Liu J, Flores-Torres S, Satyamurthy N, Petric A, Cole GM, Small GW, Huang SC, Barrio JR. Binding characteristics of radiofluorinated 6-dialkylamino-2-naphthylethylidene derivatives as positron emission tomography imaging probes for $\beta$-amyloid plaques in Alzheimer' disease. J. Neurosci 2001;21:RC189. [PubMed: 11734604]

(14). Nordberg A. PET imaging of amyloid in Alzheimer' disease. Lancet Neurol 2004;3:519-527. [PubMed: 15324720]

(15). Ono M, Wilson A, Nobrega J, Westaway D, Verhoeff P, Zhuang Z-P, Kung M-P, Kung HF. CLabeled Stilbene Derivatives as A $\beta$-aggregate-specific PET Imaging Agents for Alzheimer' Disease. Nucl. Med. Biol 2003;30:565-571. [PubMed: 12900282]

(16). Zhuang ZP, Kung MP, Wilson A, Lee CW, Plossl K, Hou C, Holtzman DM, Kung HF. Structureactivity relationship of imidazo[1,2-a]pyridines as ligands for detecting beta-amyloid plaques in the brain. J. Med. Chem 2003;46:237-243. [PubMed: 12519062]

(17). Kung MP, Hou C, Zhuang Z-P, Zhang B, Skovronsky DM, Gur T, Lee VM-Y, Trojanowski JQ, Kung HF. IMPY: An improved thioflavin-T derivative for in vivo Labeling of $\beta$-amyloid plaques. Brain Res 2002;956:202-210. [PubMed: 12445687]

(18). Kung M-P, Hou C, Zhuang Z-P, Cross AJ, Maier DL, Kung HF. Characterization of IMPY as a potential imaging agent for $\beta$-amyloid plaques in double transgenic PSAPP mice. Euro. J. Nucl. Med. Mol. Imag 2004;31:1136-1145.

(19). Kung M-P, Hou C, Zhuang Z-P, Skovronsky D, Kung HF. Binding of two potential imaging agents targeting amyloid plaques in postmortem brain tissues of patients with Alzheimer' disease. Brain Res 2004;1025:89-105.

(20). Cai L, Chin FT, Pike VW, Toyama H, Liow J-S, Zoghbi SS, Modell K, Briard E, Shetty UH, Sinclair K, Donohue S, Tipre D, Kung M-P, Dagostin C, Widdowson DA, Green M, Gao W, Herman MM, Ichise M, Innis RB. Synthesis and Evaluation of Two ${ }^{18}$ F-Labeled 6-Iodo-2-(4'-N,Ndimethylamino)phenylimidazo[1,2-a]pyridine Derivatives as Prospective Radioligands for $\beta$ Amyloid in Alzheimer' Disease. J. Med. Chem 2004;47:2208-2218. [PubMed: 15084119]

(21). Lee C-W, Kung M-P, Hou C, Kung HF. Dimethylamino-fluorenes: Ligands for Detecting $\beta$ Amyloid Plaques in the Brain. Nucl. Med. Biol 2003;30:573-580. [PubMed: 12900283]

(22). Suemoto T, Okamura N, Shiomitsu T, Suzuki M, Shimadzu H, Akatsu H, Yamamoto T, Kudo Y, Sawada T. In vivo labeling of amyloid with BF-108. Neurosci. Res. (Amsterdam) 2004;48:65-74.

(23). Kung HF, Lee C-W, Zhuang ZP, Kung MP, Hou C, Ploss1 K. Novel stilbenes as probes for amyloid plaques. J. Am. Chem. Soc 2001;123:12740-12741. [PubMed: 11741464]

(24). Yuan W, Berman RJ, Gelb MH. Synthesis and evaluation of phospholipid analogs as inhibitors of cobra venom phospholipase A2. J. Am. Chem. Soc 1987;109:8071-8081.

(25). Cox DP, Terpinski J, Lawrynowicz W. “Anhydrous” tetrabutylammonium fluoride: a mild but highly efficient source of nucleophilic fluoride ion. J. Org. Chem 1984;49:3216-3219.

(26). Miyashita N, Yoshikoshi A, Grieco AP. Pyridinium p-toluenesulfonate. A mild and efficient catalyst for the tetrahydropyranylation of alcohols. J. Org. Chem 1977;42:3772-3774.

(27). Musso DL, Cochran FR, Kelley JL, McLean EW, Selph JL. Indanylidenes.1. Design and Synthesis of (E)-2-(4,6-Difluoro-1-indanylidene)acetamide, a Potent, Centrally Acting Muscle Relaxant with Antiinflammatory and Analgesic Activity. J. Med. Chem 2003;46:399-408. [PubMed: 12540239]

(28). McGowan E, Sanders S, Iwatsubo T, Takeuchi A, Saido T, Zehr C, Yu X, Uljon S, Wang R, Mann D, Dickson D, Duff K. Amyloid phenotype characterization of transgenic mice overexpressing both mutant amyloid precursor protein and mutant presenilin 1 transgenes. Neurobiol. Dis 1999;6:231244. [PubMed: 10448051]

(29). Westerman MA, Cooper-Blacketer D, Mariash A, Kotilinek L, Kawarabayashi T, Younkin LH, Carlson GA, Younkin SG, Ashe KH. The relationship between Abeta and memory in the Tg2576 mouse model of Alzheimer' disease. J. Neurosci 2002;22:1858-1867. [PubMed: 11880515] 
(30). van Dooren T, Dewachter I, Borghgraef P, van Leuven F. Transgenic mouse models for APP processing and Alzheimer's disease: early and late defects. Subcell Biochem 2005;38:45-63. [PubMed: 15709472]

(31). Hsiao K, Chapman P, Nilsen S, Eckman C, Harigaya Y, Younkin S, Yang F, Cole G. Correlative memory deficits, $A \beta$ elevation, and amyloid plaques in transgenic mice. Science 1996;274:99-102. [PubMed: 8810256]

(32). Cleary JP, Walsh DM, Hofmeister JJ, Shankar GM, Kuskowski MA, Selkoe DJ, Ashe KH. Natural oligomers of the amyloid-beta protein specifically disrupt cognitive function. Nat Neurosci 2005;8:79-84. [PubMed: 15608634]

(33). Bitan G, Kirkitadze MD, Lomakin A, Vollers SS, Benedek GB, Teplow DB. Amyloid beta -protein (Abeta) assembly: Abeta 40 and Abeta 42 oligomerize through distinct pathways. Proc. Natl. Acad. Sci. U.S.A 2003;100:330-335. [PubMed: 12506200]

(34). Serpell LC, Sunde M, Benson MD, Tennent GA, Pepys MB, Fraser PE. The protofilament substructure of amyloid fibrils. J. Mol. Biol 2000;300:1033-1039. [PubMed: 10903851] 


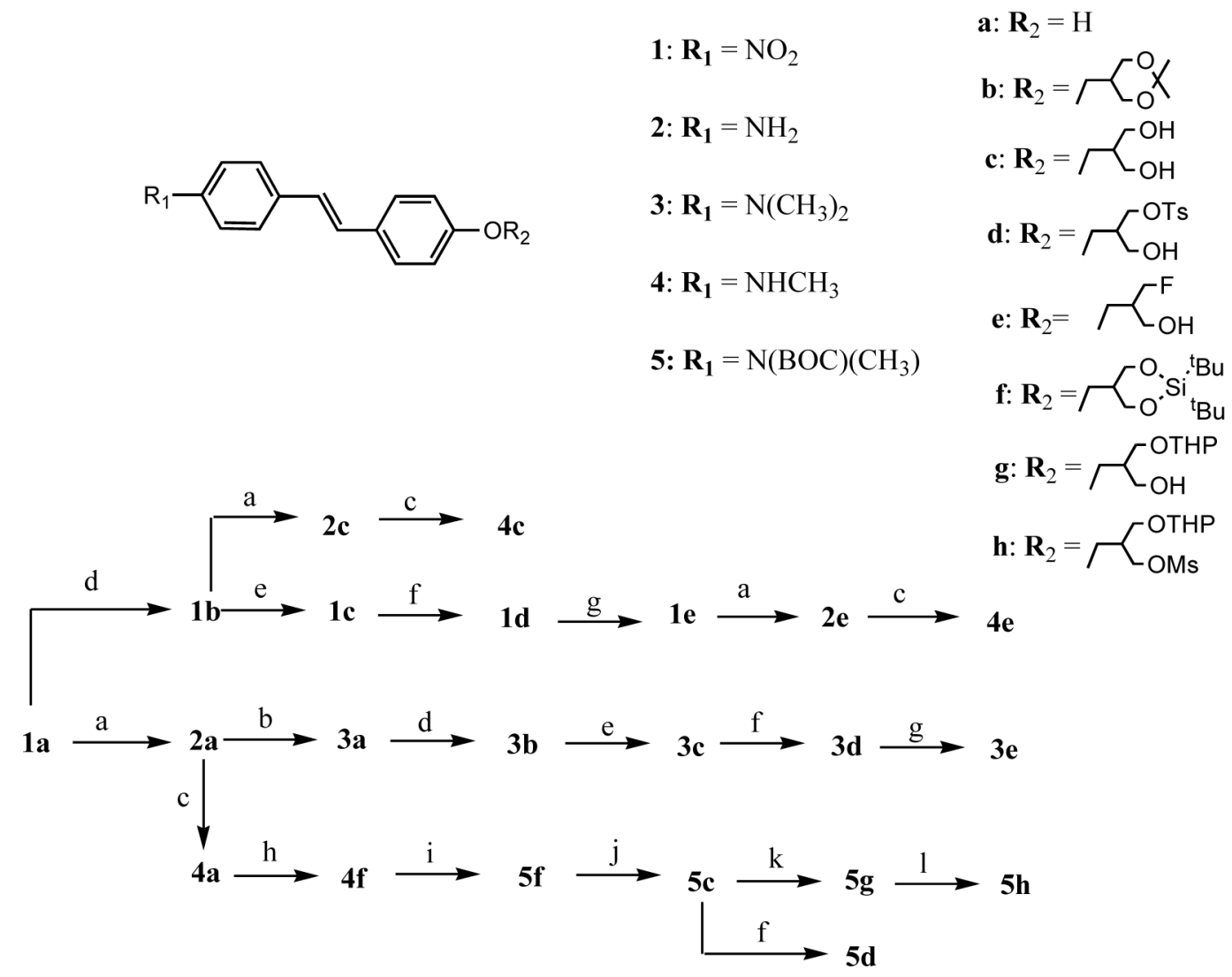

Scheme 1.

a) $\mathrm{SnCl}_{2}, \mathrm{HCl}(\mathrm{c}), \mathrm{EtOH}$; b) (CHO)n, $\mathrm{NaBH}_{3} \mathrm{CN}, \mathrm{AcOH}, \mathrm{rt}$; c) (1) $\mathrm{NaOMe}, \mathrm{MeOH},(\mathrm{CHO})_{n}$; (2) $\mathrm{NaBH}_{4}$; d) 8m, $\mathrm{K}_{2} \mathrm{CO}_{3}$, DMF, $100{ }^{\circ} \mathrm{C}$; e) $\mathrm{HCl}, \mathrm{CH}_{3} \mathrm{COCH}_{3}$, rt; f) TsCl, $\mathrm{Py}, 0^{\circ} \mathrm{C}$; g) TBAF, THF, reflux; h) 8n, $\mathrm{K}_{2} \mathrm{CO}_{3}$, DMF, $100{ }^{\circ} \mathrm{C}$; i) (BOC) ${ }_{2} \mathrm{O}$, THF, reflux; j) TBAF (1 M), THF, rt; k) DHP, PPTS, DCM, rt; 1) MsCl, Et 3 N, DCM, rt. 


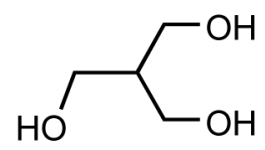

6

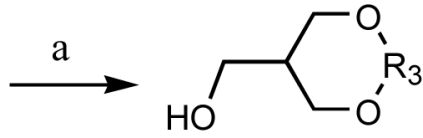

7

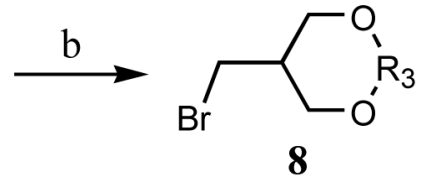

8 $\mathbf{m}: \mathbf{R}_{\mathbf{3}}=\mathrm{C}^{\prime}$

n: $\mathbf{R}_{\mathbf{3}}=\mathrm{Si}^{\prime}$<smiles>C[AsH3]</smiles>

$\mathrm{Bu}$

Scheme 2.

a) 7m: $\left(\mathrm{CH}_{3} \mathrm{O}\right)_{2} \mathrm{C}(\mathrm{CH} 3)_{2}$, TsOH, reflux; 7n: $\mathrm{HOBT}, \mathrm{Si}(\mathrm{t}-\mathrm{Bu})_{2} \mathrm{Cl}_{2}$, Et3N, DCM, reflux; b) $\mathrm{CBr}_{4}, \mathrm{PPh}_{3}, \mathrm{Py}, \mathrm{DCM}$, rt. 

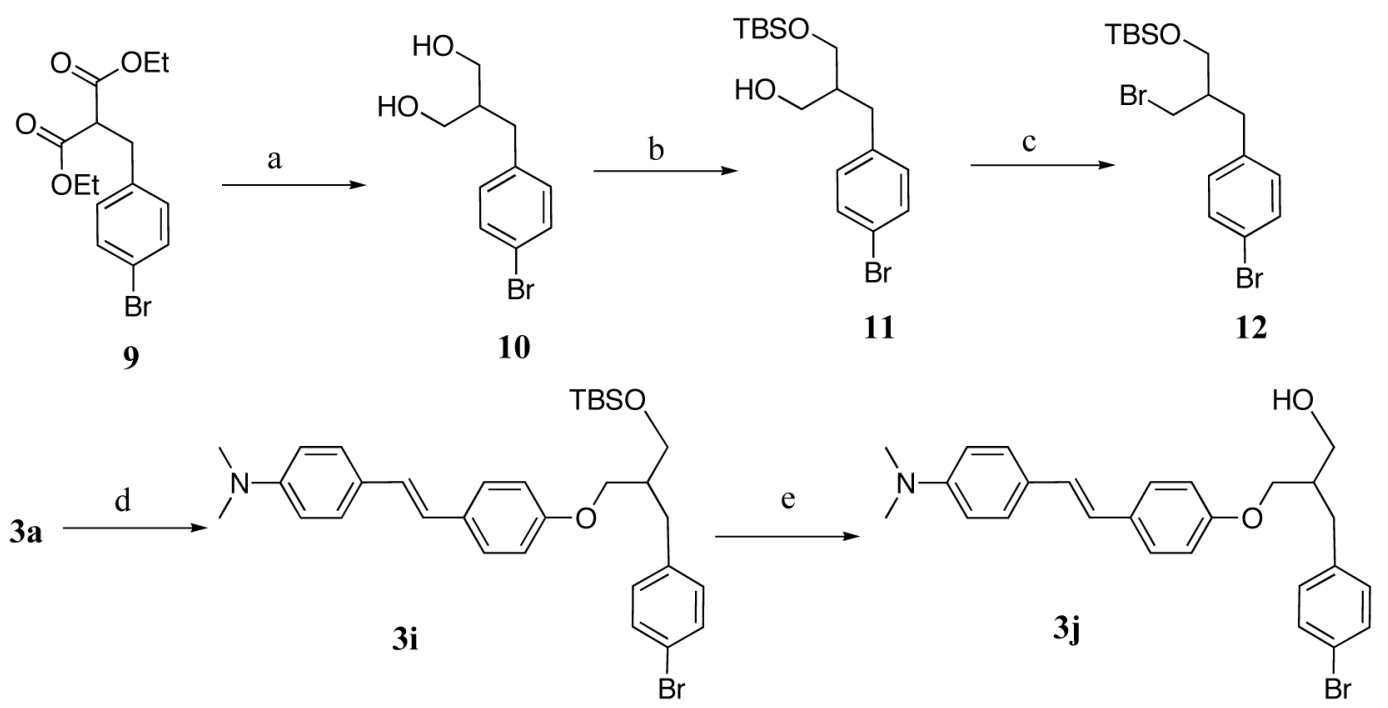

Scheme 3.

a) DIBALH, THF, $0{ }^{\circ} \mathrm{C}$; b) $\mathrm{TBSCl}, \mathrm{Et}_{3} \mathrm{~N}, \mathrm{DCM}$, rt; c) $\mathrm{CBr}_{4}, \mathrm{PPh}_{3}, \mathrm{DCM}$, rt; d) $\mathrm{K}_{2} \mathrm{CO}_{3}, \mathbf{1 2}$, $\mathrm{DMF}, 100{ }^{\circ} \mathrm{C}$; e) $\mathrm{TBAF}(1 \mathrm{M}), \mathrm{THF}, \mathrm{rt}$. 


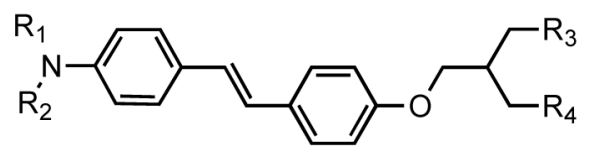

3d: $\mathrm{R}_{1}=\mathrm{R}_{2}=\mathrm{CH}_{3}, \mathrm{R}_{3}=\mathrm{OTs}, \mathrm{R}_{4}=\mathrm{OH}$

5d: $\mathrm{R}_{1}=\mathrm{CH}_{3}, \mathrm{R}_{2}=$ BOC, $\mathrm{R}_{3}=\mathrm{OMs}, \mathrm{R}_{4}=$ OTHP

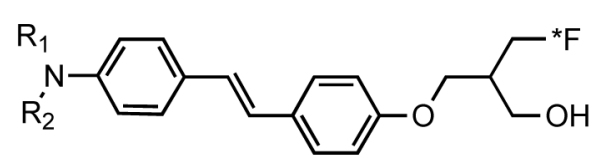

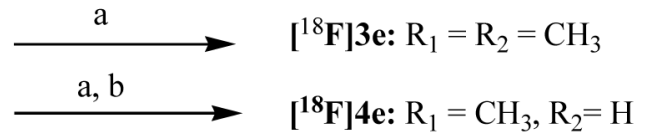

Scheme 4.

(a) $\left[{ }^{18} \mathrm{~F}\right] \mathrm{HF} / \mathrm{K}_{2} \mathrm{CO}_{3} / \mathrm{K} 222 \mathrm{DMSO}$, (b) aq $\mathrm{HCl}$ 


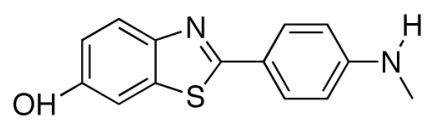

$\left[{ }^{11} \mathrm{C}\right] \mathrm{PIB}$

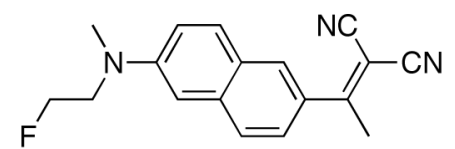

$\left[{ }^{18}\right.$ F $F D D N P$<smiles>CNc1ccc(/C=C/c2ccc(O)cc2)cc1</smiles>

$\left[{ }^{11} \mathrm{C}\right] \mathrm{SB}-13$

Fig.1.

Structures of PET imaging agents proven to target amyloid plaques in AD patients 
(A)

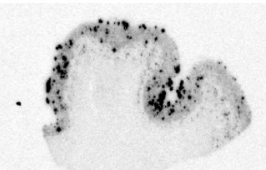

(B)

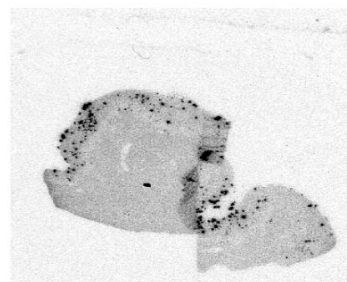

Fig.2.

In vitro autoradiography of brain sections from $\mathrm{AD}$ patients labeled with $\left[{ }^{18} \mathrm{~F}\right] \mathbf{3 e}(\mathrm{A})$ and $\left[{ }^{18} \mathrm{~F}\right]$ $4 \mathbf{e}(\mathrm{B})$. The $\mathrm{A} \beta$ plaques were clearly labeled with both ${ }^{18} \mathrm{~F}$ tracers with low background labeling. 
(A)

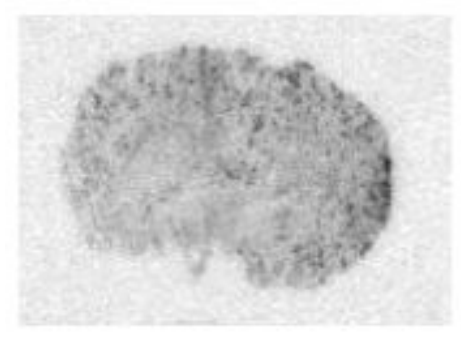

(B)

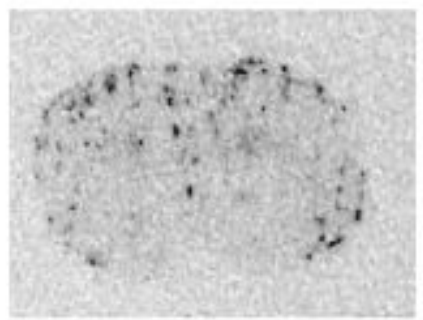

Fig.3.

In vivo plaque labeling visualized by ex vivo autoradiogram (A) $\left[{ }^{18} \mathrm{~F}\right] 3 \mathrm{e}$ in a APP/PS1 mouse brain (B) $\left[{ }^{18} \mathrm{~F}\right] 4 \mathrm{e}$ in a Tg2576 mouse. The animal was injected via tail vein with $270 \mu \mathrm{Ci}\left[{ }^{18} \mathrm{~F}\right]$ 3e or $260 \mu \mathrm{Ci}\left[{ }^{18} \mathrm{~F}\right] 4 \mathbf{e}$ and sacrificed $2 \mathrm{hr}$ (for $\left[{ }^{18} \mathrm{~F}\right] \mathbf{3 e}$ ) or $1 \mathrm{hr}$ (for $\left[{ }^{18} \mathrm{~F}\right] \mathbf{4 e}$ ) after tracer injection. 


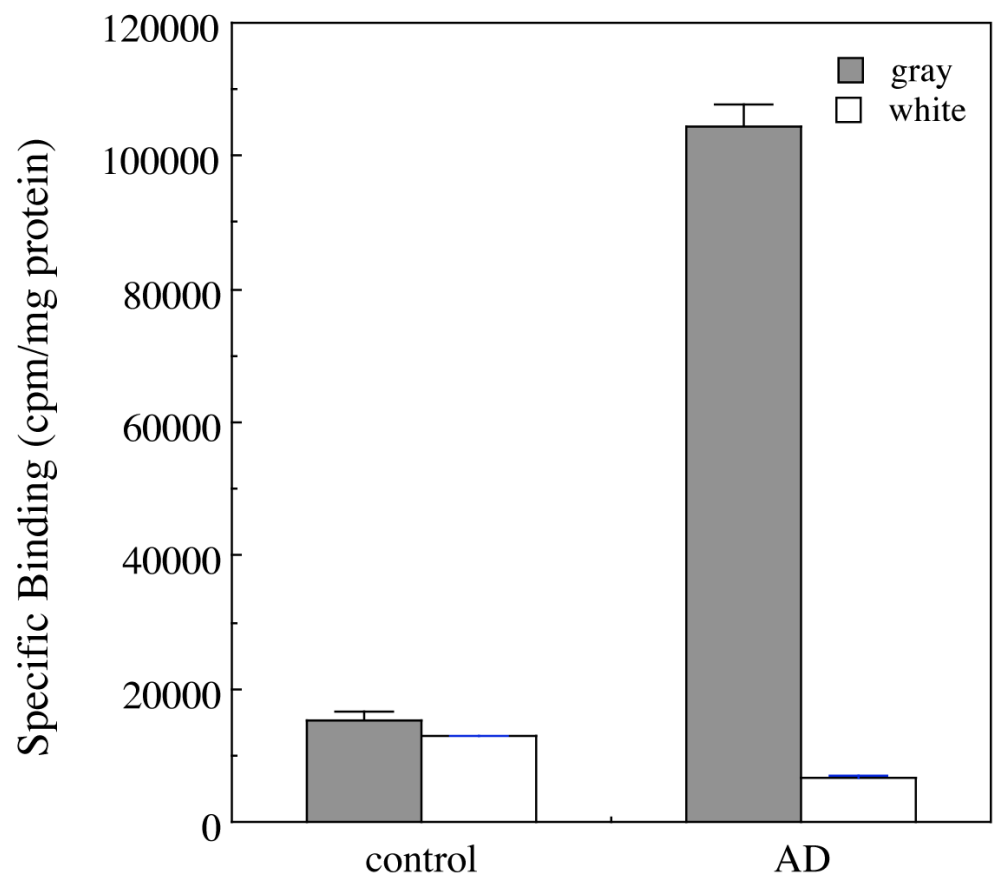

Fig.4.

$\left[{ }^{18} \mathrm{~F}\right] \mathbf{4 e}$ showed binding to $\mathrm{AD}$ and control tissue homogenates prepared from dissected gray and white matter of cortical regions. High specific binding was detected mainly in gray matter with relatively low binding in white matter homogenates. In contrast, homogenates from the control showed significantly lower specific binding of $\left[{ }^{18} \mathrm{~F}\right] \mathbf{4 e}$. 
Table 1

Inhibition constants $(\mathrm{Ki}, \mathrm{nM})$ of compounds on I-125-IMPY binding to amyloid plaques in AD brain homogenates

\begin{tabular}{|c|r|l|r|}
\hline Compound & $\begin{array}{r}\mathbf{K i} \pm \mathbf{S E M} \\
(\mathbf{n M})\end{array}$ & Compound & $\begin{array}{c}\mathbf{K i} \pm \mathbf{S E M} \\
(\mathbf{n M})\end{array}$ \\
\hline $\mathbf{2 a}$ & $95 \pm 8.0$ & $\mathbf{3 e}$ & $15 \pm 6$ \\
\hline $\mathbf{2 e}$ & $15 \pm 4.0$ & $\mathbf{3 j}$ & $80 \pm 20$ \\
\hline $\mathbf{3 a}$ & $1.1 \pm 0.2$ & $\mathbf{4 a}(\mathbf{S B}-13)$ & $1.2 \pm 0.2^{*}$ \\
\hline $\mathbf{3 b}$ & $59 \pm 10$ & $\mathbf{4 c}$ & $32.5 \pm 5.0$ \\
\hline $\mathbf{3 c}$ & $38 \pm 5$ & $\mathbf{4}$ & $5.0 \pm 1.2$ \\
\hline $\mathbf{3 d}$ & $150 \pm 30$ & $\mathbf{P I B}$ & $2.8 \pm 0.5$ \\
\hline
\end{tabular}

Each value was determined three times with duplicate for each measurement.

$*$

* The value was reported previously 19 . 
Table 2

Biodistribution in ICR mice after an iv injection of [18F]tracers in $0.1 \%$ BSA (\%dose/g, avg of 3 mice \pm SD)

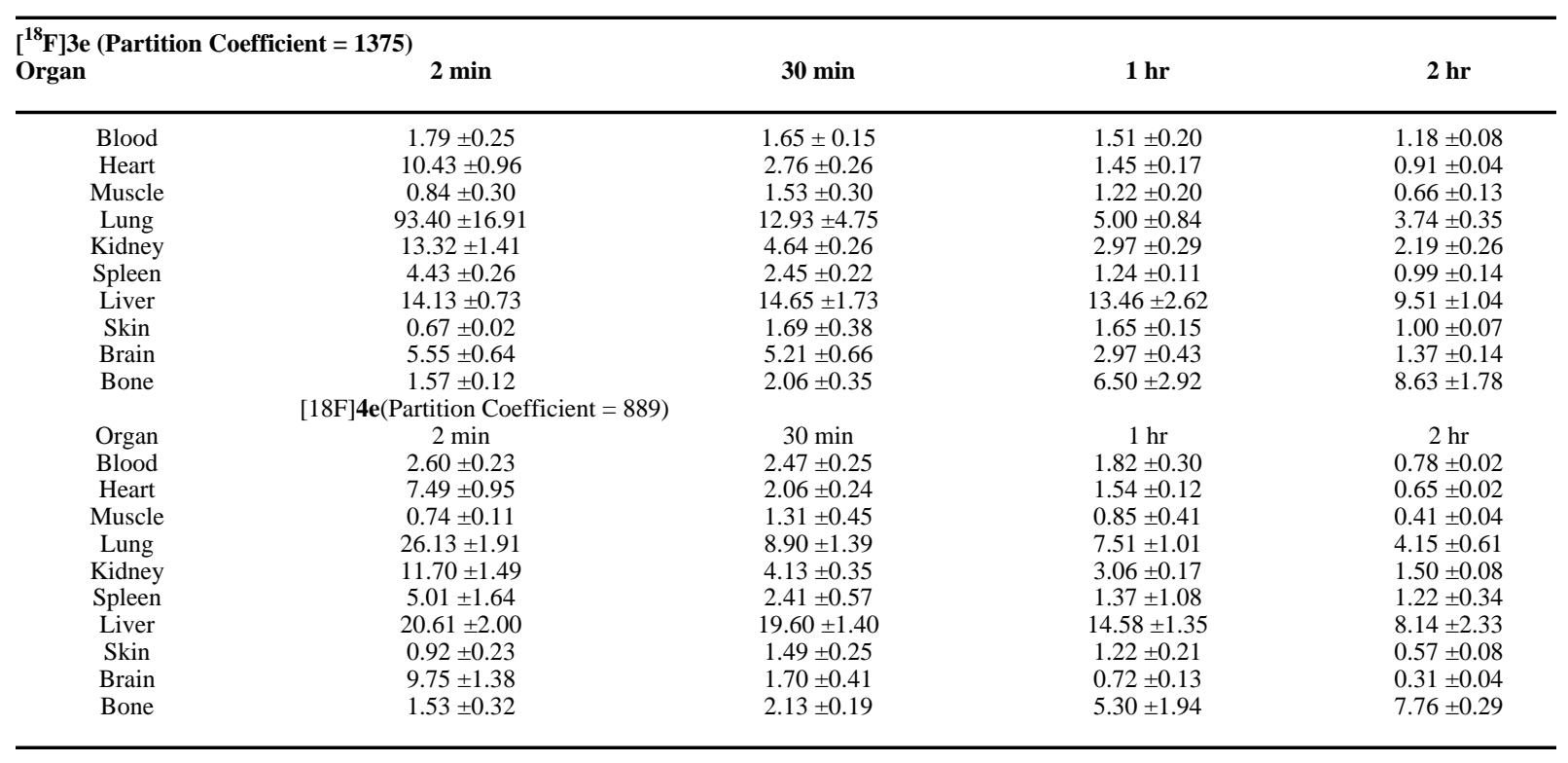

